\title{
DOSSIÊ
}

\section{Imagem e desmatamento: paisagem, perspectiva e}

expansão colonial

\section{Image and deforestation: landscape, perspective and colonial expansion}

\section{Pedro Urano}

É cineasta e artista visual. Mestre em História das Ciências, das Técnicas e Epistemologia (UFRJ). Doutorando em Linguagens Visuais no PPGAV-EBA (UFRJ).

\section{André Reyes Novaes}

É professor associado do Departamento de Geografia Humana e do Programa de Pós-Graduação em Geografia da Universidade do Estado do Rio de Janeiro.

\section{RESUMO}

0 artigo analisa um grupo de imagens (iluminuras, pinturas, mapas e baixosrelevos) que figuram a prática do desmatamento de áreas florestadas. Compreendido num intervalo de cerca de cem anos, entre meados dos séculos XV e XVI, o recorte temporal escolhido é contemporâneo do surgimento do conceito de paisagem na Europa, do desenvolvimento da perspectiva unifocal e da expansão colonial, que 'exportou' uma maneira característica de se relacionar com o território através do Atlântico. A história do desmatamento também é visual.

\section{PALAVRAS-CHAVE: \\ Paisagem; \\ Desimatamento; \\ Imagem; \\ Perspectiva; \\ Expansão colonial.}

Dossiê 0 Pensamento Ecológico - https://revistaecopos.eco.ufrj.br/

ISSN $2175-8689$ - v. 23, n. 2, 2020

DOI: 10.29146/eco-pos.v23i2.27507 


\section{ABSTRACT}

The article analyzes a group of visual images (illuminated manuscripts, paintings, maps and bas-relieves) that picture the ancient practice of deforestation. Encompassing a hundred years' time, from mid-15th to mid-16th century, the chosen period is contemporary with the emergence of the concept of landscape in Europe, the development of unifocal perspective, and colonial expansion, which 'exported' through the Atlantic a particular way of relating to territory. The history of deforestation is also visual.

KEYWORDS: Landscape; Deforestation; Image; Perspective; Colonial expansion.

\section{RESUMEN}

El artículo analiza un grupo de imágenes (iluminaciones, pinturas, mapas y bajorrelieves) que representan la práctica de la deforestación. Con un intervalo de aproximadamente cien años, entre mediados de los siglos XV y XVI, el marco de tiempo elegido es contemporáneo con el surgimiento del concepto de paisaje en Europa, con el desarrollo de la perspectiva unifocal y con la expansión colonial, que 'exportó' una forma característica de relacionarse con el territorio al otro lado del Atlántico. La historia de la deforestación también es visual.

PALABRAS CLAVE: Paisaje; Deforestación; Imagen; Perspectiva; Expansión colonial.

\section{In tro dução}

Um dos mais antigos registros de derrubada de uma floresta para o uso de sua madeira remonta à primeira obra literária de que se tem notícia, a Epopeia de Gilgamesh. Composto por 12 tábuas de argila com inscrições cuneiformes, este antigo poema épico mesopotâmico descreve, nas tábuas quarta e quinta, a chamada 'Jornada na Floresta', em que Gilgamesh, rei divinizado da cidade-estado suméria de Uruk, adentra uma floresta de cedros que se estende "por dez mil léguas em todos os sentidos" (Anônimo, 2011, p.71) e é guardada pelo "feroz gigante Humbaba" (Anônimo, 2011, p.69). 0 motivo declarado para tão perigosa empresa é erigir um monumento aos deuses e assim inscrever seu nome na história. "No lugar onde estão inscritos os nomes de varões ilustres, deixarei gravado o meu nome; e onde nome de homem algum jamais foi inscrito, mandarei erigir um monumento aos deuses" (Anônimo, 2011, p.70). Segundo o poema, antes

\section{Dossiê 0 Pensamento Ecológico - https://revistaecopos.eco.ufrj.br/}

ISSN 2175-8689 - v. 23, n. 2, 2020

DOI: 10.29146/eco-pos.v23i2.27507 
de Gilgamesh, nenhum homem civilizado jamais havia ousado entrar naquela floresta, que estava sob a guarda do feroz semideus Humbaba. A missão de Humbaba era justamente proteger a natureza da cobiça humana.

Ao primeiro golpe do machado de Gilgamesh, Humbaba explode de ira e tem início o violento embate entre os dois, vencido pelo Rei de Uruk. Com a ajuda de seu fiel companheiro Enkidu, Gilgamesh então derruba inúmeros cedros, que são transportados pelo rio Eufrates até sua cidade natal. A epopeia de Gilgamesh apresenta elementos que se tornariam emblemáticos da relação que as sociedades do 'Ocidente'1 manteriam com as florestas: seu uso como fonte de matéria-prima para construção civil e o transporte fluvial dos troncos de madeira até a cidade.

Neste ensaio, apresentamos uma breve genealogia dessa maneira de encarar o ambiente para, em seguida, reunir um grupo de imagens que são simultaneamente expressão deste modo de ver a floresta e figuração de sua destruição. Elegemos como recorte temporal um período de cerca de cem anos que, compreendido entre meados dos séculos XV e XVI, é contemporâneo do surgimento do conceito de paisagem no Ocidente, do desenvolvimento da perspectiva unifocal e da expansão desse modelo de relação com o território através do Atlântico. A história do desmatamento também é visual.

\footnotetext{
${ }^{1}$ Ao utilizar o termo Ocidente no presente texto não buscamos caracterizar uma entidade autoevidente ou concreta, mas sim uma narrativa histórica associada a um constructo social. Como evidencia o filólogo Edward Said (1999, p.16), Oriente e Ocidente não estão "apenas lá", mas são produzidos por meio de discursos, instituições, vocabulários, imaginários e burocracias coloniais. Segundo o autor, os "lugares, regiões e setores geográficos tais como o Oriente e o Ocidente são feitos pelo homem", e a oposição entre essas entidades foi fundamental na definição da identidade europeia. Para Said (1999, p.14), "a cultura europeia ganhou em força e identidade comparando-se com o Oriente como uma espécie de identidade substituta e até mesmo subterrânea". Conscientes de como os termos são produções culturais materializadas na historiografia, utilizamos Ocidente nesse texto como recorte narrativo, sem desconsiderar trocas e intercâmbios fundamentais na produção de imagens e histórias do desmatamento.
}

Dossiê O Pensamento Ecológico - https://revistaecopos.eco.ufrj.br/

ISSN $2175-8689$ - v. 23, n. 2, 2020

DOI: 10.29146/eco-pos.v23i2.27507 
Imagens são seres ambivalentes, performam uma dinâmica que oscila entre a transparência de uma janela e a opacidade de uma superfície ${ }^{2}$. São a um só tempo testemunhas interessadas e agentes produtivos de personagens e identidades elas fazem devir o sujeito mesmo que as produz ${ }^{3}$. Não podem, portanto, serem dissociadas do saber próprio de uma época nem de suas crenças, ainda que tampouco devam ser encaradas como cópia fiel de qualquer paisagem ou acontecimento. Mantendo esse caráter ambivalente no horizonte, no entanto, podemos delas nos servir como vestígios imaginais de outros tempos, como "fenômenos antropológicos totais, cristalizações particularmente significativas de uma cultura num determinado momento de sua história", como defendia a abordagem iconológica de Aby Warburg (Didi-Huberman, 2013, p. 40).

Muitos autores têm alertado para os perigos associados aos métodos iconográficos e iconológicos, que podem levar a associações simplistas e imediatas entre imagens e contextos sociais amplos (Ginzburg, 1989; Burke, 2004). Neste ensaio, não buscaremos decodificar 'o' significado das imagens e muito menos associar seus motivos a 'espíritos de época' ou valores simbólicos homogêneos. Para evitar a elaboração de argumentos circulares comuns aos iconólogos ${ }^{4}$, que “correm o risco de descobrir nas imagens exatamente aquilo que eles já sabiam que lá se encontrava" (Burke 2004, p.50), buscamos reunir uma série de imagens sobre o desmatamento de forma livre e ensaística. As imagens não serão aqui, portanto, encaradas nem como registro objetivo de um processo histórico, nem como materialidades que "revelam a atitude básica de uma nação, um período,

\footnotetext{
${ }^{2}$ Nos referimos aqui à categorização proposta para arte por Arthur Danto, que divide as teorias da imagem entre teorias da transparência e teorias da opacidade. (Danto, 1981, p.159 apud Alloa, 2015, p.12)

${ }^{3}$ Essa agência das imagens é destacada por Mondzain (2015, p.39): “As operações imaginantes são inseparáveis dos gestos que produzem os signos que, por essa razão, permitem os processos de identificação e a separação sem as quais não haveria sujeito."

4 Para uma sistematização das críticas à iconologia entre "argumentos circulares" e "negligências ao observador", ver Novaes (2013).
}

Dossiê 0 Pensamento Ecológico - https://revistaecopos.eco.ufrj.br/

ISSN $2175-8689$ - v. 23, n. 2, 2020

DOI: 10.29146/eco-pos.v23i2.27507 
uma classe, uma crença religiosa ou filosófica" (Panofsky, 1978). Nosso objetivo foi encadear uma série de imagens e histórias sobre o desmatamento, sem a pretensão de identificação de padrões formais ou de estabelecer classificações temáticas. A intenção principal deste ensaio é, portanto, desenvolver um 'pensamento por imagens', tendo como inspiração as séries de imagens criadas no Atlas Mnemosyne, de Aby Warburg (Didi-Huberman, 2013, p.383). É na articulação entre imagens, paisagens e perspectivas que buscaremos tecer uma narrativa sobre a memória do desmatamento, considerando a figuração da retirada de florestas situadas tanto na Europa quanto em espaços coloniais, como o Brasil. Selecionadas e justapostas - articuladas pela montagem -, imagens produzem constelações significativas, capazes de trazer para primeiro plano o que até então eram detalhes do fundo, revelando outras perspectivas e visualidades.

\section{Matéria-prima da antiguidade (e além)}

Os passos de Gilgamesh foram seguidos por soberanos de outras cidadesestado da Mesopotâmia que também organizaram, ao longo da última metade do terceiro milênio a.C., expedições floresta adentro em busca de madeira, com o objetivo declarado de desenvolverem suas próprias cidades e assim inscreverem seus nomes na história. Em um relato compilado por Oppenheim (1969, p.268), por exemplo, Gudea, rei de Lagash, descreve como se amarravam os troncos de madeira uns aos outros de maneira a criar estruturas flutuantes que eram utilizadas como embarcações rudimentares no trajeto pelo rio. No reino de Gudea, determinados tipos de madeira eram considerados tão valiosos que eram guardados no tesouro real, cujo acesso dependia da autorização expressa do soberano. As montanhas recebiam os nomes das espécies de árvores dominantes em suas encostas, e a busca por madeira muitas vezes determinava a relação com reinos vizinhos. Quando as florestas próximas se tornavam descampados e a 
produção de madeira declinava, as tropas do reino marchavam rumo à conquista de outras regiões ainda florestadas. As encostas nuas, por sua vez, tornavam-se vulneráveis à erosão. A camada superficial do solo, composta por rochas sedimentares ricas em sal, era carregada pela chuva montanha abaixo até a margem dos rios, e por estes até os canais de irrigação agrícola onde os detritos se depositavam, exigindo dragagem constante. Após cerca de 1500 anos de bem sucedida agricultura, os campos sumérios passaram a sofrer um processo de salinização contemporâneo da extração de madeira das encostas vizinhas, que, diferentemente do assoreamento, revelou-se irreversível, resultando no declínio da produção agrícola e, logo, na decadência da região.

Esta cadeia de acontecimentos - que se repetiria, em diferentes graus de complexidade, em outras paisagens e civilizações - é apresentada na História das florestas $^{5}$ narrada pelo escritor estadunidense John Perlin. Perlin acompanha o percurso da civilização ocidental, do Crescente Fértil à colonização das Américas, pela perspectiva das florestas que abasteceram e permitiram seu desenvolvimento. Sua história das florestas é uma história do desmatamento: a atitude do Ocidente frente aos biomas florestais e sua população vegetal foi consistentemente marcada pela ideia de um recurso a ser explorado.

De fato, a madeira foi a principal matéria-prima do mundo antigo. A palavra para 'madeira', tanto para gregos quanto para romanos (hulae e materia, respectivamente), era sinônimo de matéria-prima. Sua escassez exigiu a intervenção de soberanos para sua proteção e conservação, estimulou o desenvolvimento tecnológico ${ }^{6}$, assim como motivou inúmeras guerras e conflitos

\footnotetext{
${ }^{5} 0$ título original do livro de Perlin - A Forest Journey - é tomado do capítulo da Epopeia de Gilgamesh que narra a incursão à floresta de cedros guardada por Humbaba.

${ }^{6} \mathrm{O}$ alto preço da madeira estimulou o desenvolvimento de tecnologias que aumentassem seu rendimento, como a hidro-metalurgia do cobre. "Usando a hidrometalurgia, um fundidor consumia um terço do combustível (madeira) total requerido pelo procedimento ortodoxo." (Perlin, 1992, p.75). Na Grécia dos séculos IV e V a.C., a arquitetura era projetada visando o aproveitamento passivo dos raios solares no aquecimento residencial, outra maneira de reduzir o consumo de
}

\section{Dossiê 0 Pensamento Ecológico - https://revistaecopos.eco.ufrj.br/}

ISSN 2175-8689 - v. 23, n. 2, 2020

DOI: 10.29146/eco-pos.v23i2.27507 
armados. A necessidade de encontrar novas fontes desse precioso recurso natural provocou grandes deslocamentos populacionais ao longo da história. A madeira foi, até a descoberta dos combustíveis fósseis como o petróleo e o carvão mineral, a principal fonte de energia da humanidade - o material combustível que alimentava o fogo que aquecia e que permitiu a humanidade modelar a superfície do planeta de acordo com suas necessidades e interesses.

Toda sociedade, da idade do bronze ao século XIX, se desenvolveu a partir da exploração de florestas inicialmente abundantes que, com o tempo, davam lugar a campos de pastagem, lavouras para a agricultura e cidades. Da mesma maneira, a escassez de madeira determinava o declínio das civilizações ou sua expansão e domínio sobre uma nova área florestada.

No início do segundo milênio a.C., por exemplo, a madeira era tão escassa na Babilônia que as casas eram alugadas sem as portas - competia ao inquilino levar consigo suas portas para a nova residência (Perlin, 1992, p.47). A alta no preço da madeira repercutia na construção naval e civil, na metalurgia, na indústria vidreira e no aquecimento residencial. Em pouco tempo, os povos do Oriente Próximo começaram a negociar madeira com a ilha de Creta, que então conheceu acelerado desenvolvimento econômico, até que suas florestas também se tornaram escassas. Os minoanos de Creta passaram a negociar com gregos do Peloponeso, e estes, com os macedônios do norte...

Com o tempo, seja qual fosse a latitude, a economia a base de madeira ia se inscrevendo e transformando a paisagem. O processo de erosão das encostas desmatadas assoreava não só canais de irrigação ou margens fluviais, mas também portos marítimos próximos a fozes de rios. Em alguns casos, o assoreamento impedia a navegação e exigia a transferência do porto para um novo local. A cidade de Myos, na Ásia Menor, que no século V a.C. era uma cidade costeira às margens

madeira. (Perlin, 1992, p.90). Cidades como Priena foram projetadas para permitir o aquecimento solar passivo de suas edificações. (Perlin, 1992, p.99).

\section{Dossiê O Pensamento Ecológico - https://revistaecopos.eco.ufrj.br/}

ISSN $2175-8689$ - v. 23, n. 2, 2020

DOI: 10.29146/eco-pos.v23i2.27507 
do Mar Egeu, próxima à foz do Rio Menderes, testemunhou um processo de assoreamento tão intenso que, ao final do século I a.C., os detritos trazidos pelo Menderes haviam 'deslocado' a linha costeira em mais de $5 \mathrm{~km}$. A cidade portuária de Myos perdeu seu acesso ao mar Egeu e, seu entorno, transformado num pantanal alagadiço, tornou-se terreno fértil para proliferação de mosquitos. Surtos de malária se tornaram frequentes, e a cidade foi completamente abandonada no segundo século depois de Cristo.

O Império Romano, os Califados Muçulmanos, a República de Veneza e logo o restante da Europa Continental conheceriam transformações mais ou menos semelhantes, onde o desmatamento dava lugar, num primeiro momento, ao progresso material e ao crescimento das cidades e campos de cultivo, mas em poucos séculos cobrava seu custo ambiental, que resultava, seja no declínio de uma civilização (e eventual reflorestamento natural da região), seja em sua expansão para novas regiões florestadas.

\section{Paisagem e imaginário do desmatamento europeu}

Produto da interação com o agente humano, pródigo na produção de imagens, este processo de modificação da paisagem ao longo dos séculos foi flagrado em desenhos, gravuras e pinturas por seus contemporâneos. Em especial, na Europa do século XV, período ao longo do qual, segundo teóricos como Augustin Berque (1997, p.18), surge o conceito de paisagem no Ocidente.

0 conceito de paisagem abriga uma curiosa ambivalência: refere-se tanto ao ambiente físico que se apreende com o olhar, quanto à sua representação (em geral, pictórica). A paisagem, portanto, é um modo de ver (Cosgrove, 1998, p.13)

que surge num momento histórico e em territórios determinados - a Itália e 
Flandres do início do século XV7. Mais especificamente, a paisagem é um modo de ver que surge nas camadas urbanas destas duas sociedades. Como defende Berque (2013, p.27), “foi a partir das cidades que um olhar desinteressado se dirigiu para o meio ambiente, gerando representações da 'natureza' e, dessa maneira, transformando-a num objeto tanto do conhecimento (a origem da ciência moderna), quanto da pura contemplação (a origem da teoria da paisagem)."

O caráter ocularcêntrico, eminentemente visual do conceito, a emergência do observador desencarnado que ele supõe e a objetivação do ambiente que promove estão relacionados com o surgimento de uma classe social urbana de donos de terra que vivem da exploração do trabalho dos camponeses da zona rural. Identificada por Berque como 'classe ociosa' - em referência ao trabalho do sociólogo estadunidense Thorstein Veblen ${ }^{8}$-, é este grupo de indivíduos que, livres da contingência do trabalho, lança um olhar contemplativo para o ambiente. Para o camponês, trabalhar é trabalhar a terra. A experiência humana é para ele o ambiente e a transformação do ambiente, um modo de perceber que não reconhece clivagem entre natureza e cultura. Para um senhor de terras na Antuérpia ou Florença do século XV, no entanto, a distinção entre o ambiente urbano - construído pelo agente humano que vive em sociedade - e o ambiente

\footnotetext{
${ }^{7}$ Para o geógrafo francês Augustin Berque, além da Europa do Renascimento, apenas a China (quase mil anos antes dos europeus) também pode ser considerada uma civilização paisagística. Este pesquisador elencou 5 critérios para classificar uma sociedade como 'paisagística': (1) literatura escrita ou oral louvando a beleza de um lugar; (2) jardins ornamentais; (3) arquitetura pensada para contemplar a natureza; (4) pinturas representando o ambiente; (5) uma ou mais palavras que signifiquem 'paisagem'; (6) uma reflexão explícita sobre o conceito de 'paisagem' (Berque, 2013, p.31). Mitchell, por sua vez, acusa a arbitrariedade de toda determinação de origem, lembrando que a contemplação de paisagens naturais não teve início no século XV. Para admitir a invenção quatrocentista da paisagem, foi preciso, por exemplo, desconsiderar as pinturas de paisagem que adornavam as villas romanas. (Mitchell, 1994, p.11-12).

${ }^{8}$ Em sua The theory of the leisure class (1899), Veblen investiga a formação de uma classe aristocrática na sociedade feudal europeia, fenômeno relacionado aos primórdios do processo de divisão do trabalho entre ocupações consideradas nobres - em geral ligadas à guerra, ao governo ou ao sacerdócio - e aquelas vulgares - ligadas à subsistência, como a produção de alimentos, moradia e ferramentas de trabalho, historicamente desempenhadas pelas mulheres (Veblen, 2016, 1899 p.5-14).
}

Dossiê 0 Pensamento Ecológico - https://revistaecopos.eco.ufrj.br/

ISSN $2175-8689$ - v. 23, n. 2, 2020

DOI: 10.29146/eco-pos.v23i2.27507 
dito natural é clara. 0 conceito de natureza é, portanto, definido inicialmente por oposição ao ambiente urbano. A 'natureza' é o não-urbano e, dessa maneira, compreende tanto o campo cultivado pela agropecuária quanto as florestas milenares remanescentes ${ }^{9}$.

As imagens quatrocentistas que investigaremos, todas elas representações de paisagens, são também contemporâneas da invenção da perspectiva, cujo desenvolvimento pode ser observado quando as consideramos em conjunto. A perspectiva é aquilo "que impõe recuo, ponto de vista, visão objetiva, isto é, separação do sujeito e do objeto. ", defende Meneses (2002, p.28), que acusa o programa imbricado nessa tecnologia de representação visual. A perspectiva é a um só tempo produto e meio do projeto copernicano de objetificação do mundo, reafirmando a dicotomia que separa o homem da natureza e lançando, dessa maneira, as bases para a instituição do sujeito moderno - aquele que, apartado da natureza, estabelece com ela uma relação de exploração violenta e sem limites.

Uma iluminura publicada n'As Riquíssimas Horas do Duque de Berry - o mais conhecido livro de horas medieval - é a primeira imagem que gostaríamos de investigar aqui. Um livro de devoções privado que compilava preces breves, o livro de horas ${ }^{10}$ foi muito popular na Idade Média. Aquele comissionado por João de França, o Duque de Berry (1340-1416), demandou quase um século de dedicação,

\footnotetext{
${ }^{9}$ Os conceitos de 'paisagem' e 'natureza' não são universais. A maior parte das populações autóctones, como os ameríndios brasileiros por exemplo, não possuem uma palavra para 'natureza'. "A existência de uma palavra que signifique 'natureza' supõe que a natureza ou o domínio natural esteja suficientemente separado dos domínios humano ou social." (BERQUE, 2013, p.17) Segundo o xamã yanomami Davi Kopenawa: "O que vocês chamam 'natureza' é, em nossa língua, urihi $a$, a terra-floresta e sua imagem utupë vista pelos xamãs: urihinari $a$. É porque existe essa imagem que as árvores são vivas. 0 que chamamos urihinari a é o espírito da floresta, das suas árvores: huu tihiripë, das suas folhas: yaa hanaripë, e dos seus cipós: thothoxiripë. Esses espíritos são muito numerosos e brincam no seu chão. Nós os chamamos também urihi $a$, 'natureza', da mesma maneira que os espíritos animais yaroripë e mesmo os das abelhas, das tartarugas e dos caracóis. 0 poder de fertilidade da floresta, në rope $a$, também é 'natureza' para nós: ele foi criado com a floresta, é sua riqueza." (KOPENAWA, 2009, p. 8).

${ }^{10}$ Uma forma simplificada de breviário, composta majoritariamente por salmos e orações a serem ditas a cada hora canônica do dia.
}

Dossiê 0 Pensamento Ecológico - https://revistaecopos.eco.ufrj.br/

ISSN $2175-8689$ - v. 23, n. 2, 2020

DOI: 10.29146/eco-pos.v23i2.27507 
Imagem 1 - Février, folio 2., Les très tiches heures du duc de Berry

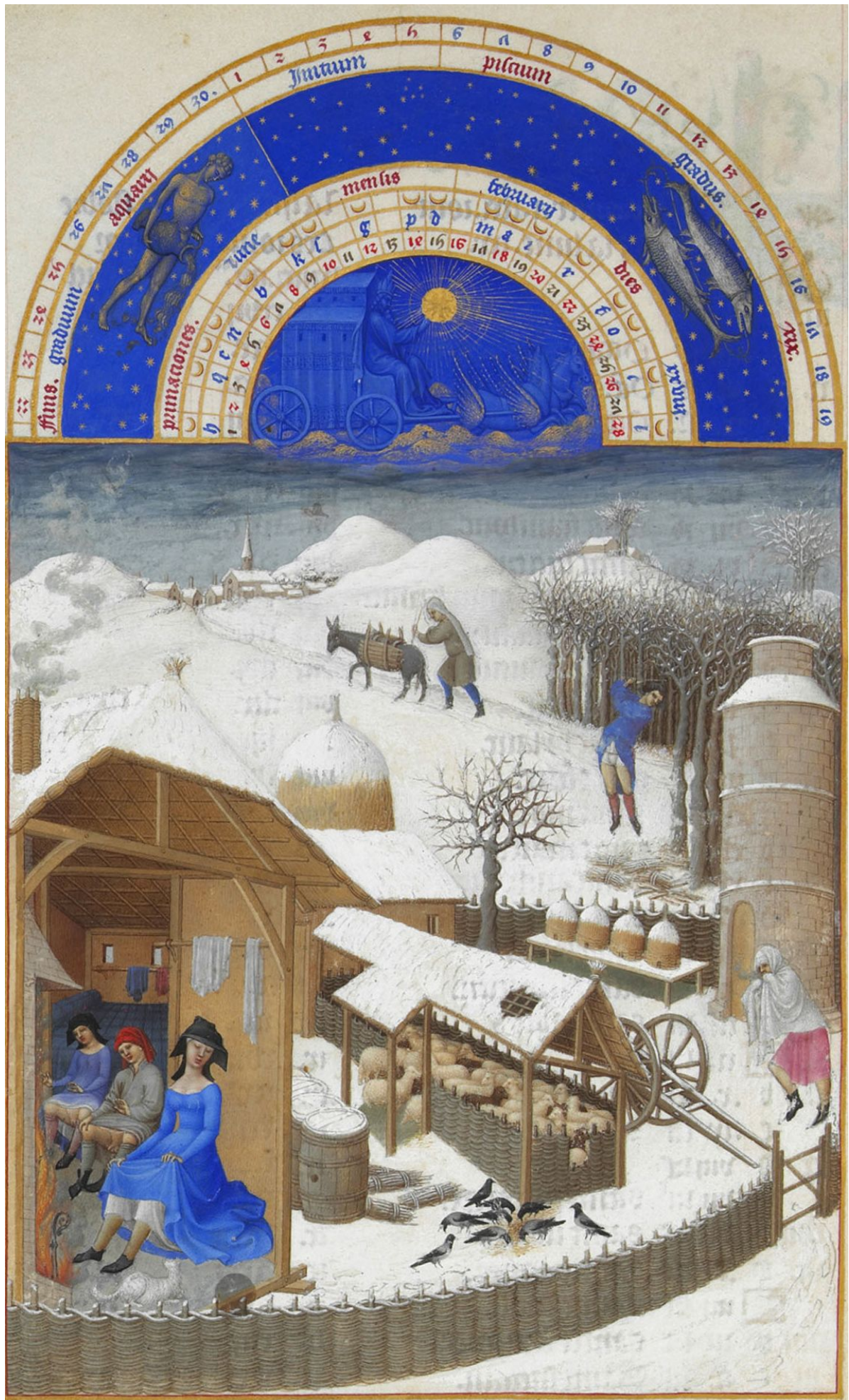

Fonte: Wikipedia

Dossiê 0 Pensamento Ecológico - https://revistaecopos.eco.ufrj.br/

ISSN $2175-8689$ - v. 23, n. 2, 2020

DOI: 10.29146/eco-pos.v23i2.27507 
e foi concluído por volta de 1489, décadas após o falecimento do aristocrata e dos artistas inicialmente responsáveis por sua realização ${ }^{11}$.

Ricamente ilustrada, a publicação se destaca pela atenção dada às paisagens, em especial nas representações associadas aos 'trabalhos do mês', um ciclo comum na Idade Média e no início da Renascença, que associava uma cena rural a cada mês do calendário.

No livro de horas do Duque de Berry, a iluminura referente ao mês de fevereiro apresenta uma paisagem rural de inverno (imagem 1). No primeiro plano, vemos um curral de ovelhas, um personagem espirrando, colmeias tradicionais de palha trançada cobertas de neve, pássaros que se alimentam de grãos espalhados no solo. 0 artista removeu uma das paredes da construção à esquerda, revelando, em seu interior, três personagens. A primeira, uma dama em trajes finos, levanta levemente a barra de seu vestido para melhor aproveitar o calor do fogo a sua frente. Um pouco atrás, um casal de camponeses não demonstra o mesmo pudor - têm as roupas levantadas até os joelhos, expondo os genitais. A meio caminho do vilarejo ao fundo, vemos um lenhador cortando árvores do bosque à direita. A seus pés, feixes de lenha descansam sobre a neve. Um pouco mais distante, outro camponês segue em direção do vilarejo com uma mula carregada de lenha. A imagem representa o uso da madeira para o aquecimento residencial tanto da construção em primeiro plano, quanto das casas da pequena vila ao fundo, assim como seu impacto no ambiente - a paisagem é predominantemente descampada. Além do pequeno bosque à direita, cuja derrubada está em andamento, sobrevivem apenas algumas árvores isoladas próximas às casas.

Na Caçada na floresta (imagem 2), de Paolo Uccello, a floresta ainda é densa e escura, como nos primeiros versos da Commedia de Dante ${ }^{12}$. As árvores

\footnotetext{
11 Os irmãos Herman, Paul e Jean Limbourg, famosos pintores renascentistas holandeses de iluminuras.
}

Dossiê 0 Pensamento Ecológico - https://revistaecopos.eco.ufrj.br/

ISSN $2175-8689$ - v. 23, n. 2, 2020

DOI: 10.29146/eco-pos.v23i2.27507 
representadas são todas da mesma espécie, têm praticamente a mesma altura e estão dispostas ordenadamente como num grid. Unidas, as copas das árvores formam um 'teto' vegetal, como em uma imensa estrutura arquitetônica onde os troncos são os pilares que, enraizados no chão, sustentam o conjunto. A distribuição ritmada dos indivíduos botânicos na paisagem selvagem produz um híbrido estranho entre natureza e artifício.

A repetição sincopada de um mesmo elemento também pode ser observada no conjunto de cavaleiros, desenhados com rostos praticamente idênticos, e, em especial, na disposição dos cachorros e cervos que encenam a caçada no centro do quadro. A semelhança extrema destes cervos e cachorros entre si permite entender a imagem não como representação de uma pequena multidão de animais diferentes, mas de um mesmo cachorro a perseguir um único cervo, como numa cronofotografia de Marey $^{13}$, em que o movimento é decupado em uma série de imagens estáticas. 0 efeito é sublinhado pelo uso da perspectiva unifocal, que garante que os elementos da pintura tenham sua escala reduzida proporcionalmente conforme se afastam do primeiro plano. Nosso olhar é capturado pela imagem e convidado a penetrar o espaço virtual tridimensional da floresta perspectivada ${ }^{14}$. A perfomance do cachorro e do cervo ao centro, por sua vez, materializa uma perspectiva temporal que aponta para um clímax (a morte do cervo pelos caçadores) que, no entanto, se encontra além do ponto de fuga, fora do alcance do olhar.

12 "Nel mezzo del cammin di nostra vita | Mi ritrovai per una selva oscura, | Che la diritta via era smarrita." Em português, "Da nossa vida, em meio da jornada, | Achei-me numa selva tenebrosa, | Tendo perdido a verdadeira estrada." (Dante, 2003, p. 17) Um tema caro ao imaginário medieval, a floresta escura é misteriosa, selvagem e ameaçadora. Um lugar onde nem tudo é o que parece ser, onde é difícil discernir amigos de inimigos.

13 Étienne-Jules Marey, cientista francês, inventor da cronofotografia.

${ }^{14}$ Segundo o historiador da arte britânico Martin Kemp, que acompanhou o restauro da pintura nos anos 80 , ao observar, através da técnica conhecida como reflectografia de infravermelho, o desenho a lápis sob as camadas de tinta, descobre-se um plano térreo reticulado, cujas paralelas convergem para um ponto de fuga central.

Dossiê 0 Pensamento Ecológico - https://revistaecopos.eco.ufrj.br/

ISSN $2175-8689$ - v. 23, n. 2, 2020

DOI: 10.29146/eco-pos.v23i2.27507 


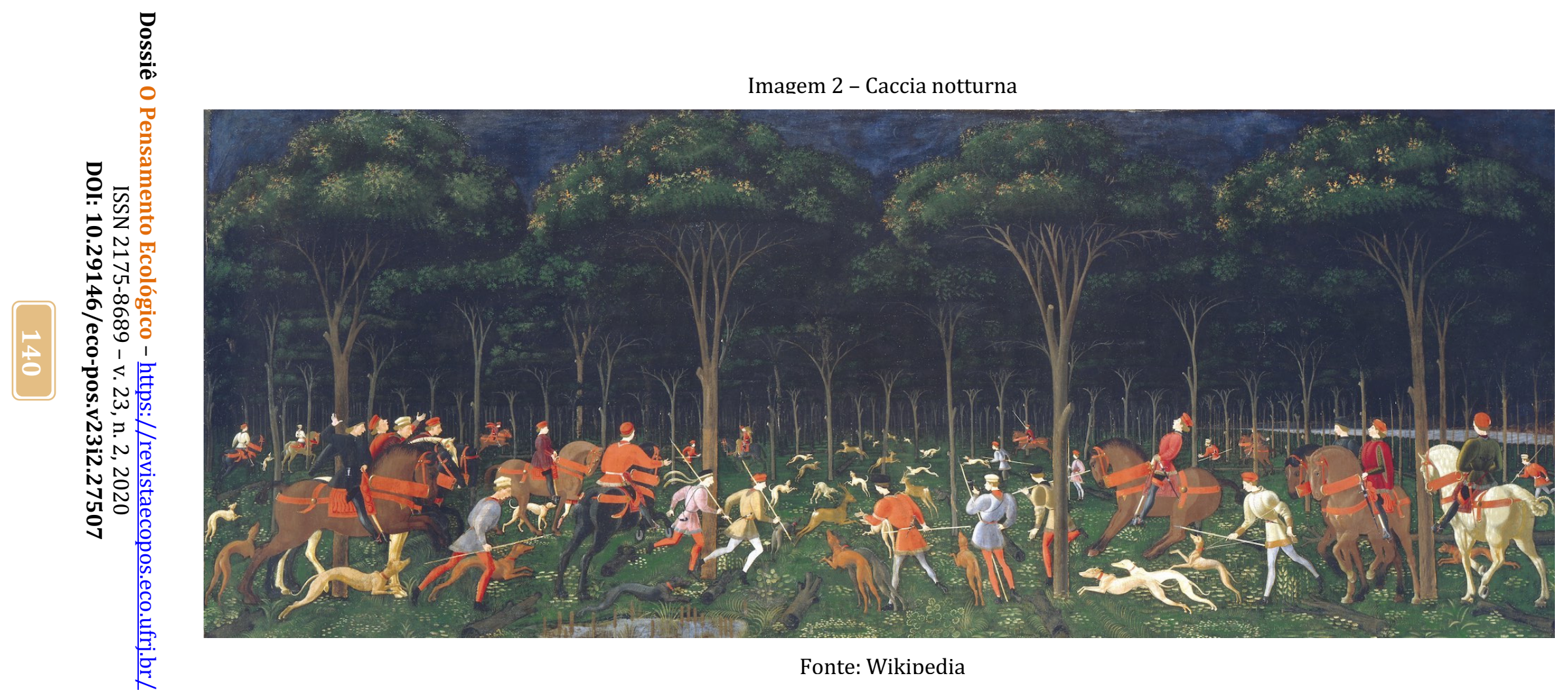


Paolo di Dono é considerado um dos mestres de sua época na perspectiva, na paisagem e na representação da natureza. 0 apelido 'Uccello' - 'pássaro' em italiano - evoca justamente suas representações fidedignas de animais. Em sua Caçada na floresta, seu olhar minucioso flagrou troncos inteiros espalhados pelo chão, a maior parte dos quais apontando na direção do ponto de fuga - apesar de também uma característica de florestas ancestrais, a quantidade de troncos no solo na pintura de Uccello, associadas às árvores podadas em primeiro plano, não deixa de sugerir uma curiosa articulação visual entre desmatamento e perspectiva. Com atenção, se divisa uma parte menos densa da floresta, com troncos pelo chão (onde acontece a caçada) e uma floresta impenetrável ao fundo. 0 desmatamento pontual de áreas de floresta comumente antecedia as caçadas promovidas pela aristocracia europeia da época ${ }^{15}$.

Na série de quatro pinturas Nastagio Degli Onesti (1483), Sandro Botticelli ilustra a história homônima, que integra o Decamerão de Giovanni Boccaccio (imagens 3, 4, 5 e 6). 0 enredo narra as desventuras de Nastagio Degli Onesti, um jovem aristocrata da cidade de Ravena que se apaixona por uma donzela de uma família mais nobre que a sua, mas não tem seu amor correspondido. Após gastar grande parte de sua fortuna com presentes para sua amada, Nastagio é convencido por seus amigos a deixar a cidade por um tempo, com o intuito de finalmente esquecer a donzela, descrita por Boccaccio como cruel e perversa. Uma tarde, num passeio pelo bosque, Nastagio é surpreendido por outra donzela que corre nua em sua direção, perseguida por dois cães bravios e por um cavaleiro que, montado num cavalo branco, brande sua espada no ar enquanto a ameaça. Indignado,

\footnotetext{
${ }^{15}$ No Livro de Horas do Duque de Berry, a ilustração referente ao mês de dezembro também representa uma caçada que acontece em uma clareira na floresta. De fato, na Europa medieval, as primeiras incursões numa floresta eram comumente motivadas pela caça, a que se seguiam, podemos especular, a abertura de clareiras. Ou talvez a abertura de clareiras fosse uma necessidade do artista que, de outra maneira, não seria capaz de representar a cena da caçada, oculta no interior da floresta - um procedimento similar à retirada de paredes para observar uma cena no interior de uma casa, como acontece na ilustração trabalhada neste ensaio, referente ao mês de fevereiro.
}

Dossiê O Pensamento Ecológico - https://revistaecopos.eco.ufrj.br/

ISSN $2175-8689$ - v. 23, n. 2, 2020

DOI: 10.29146/eco-pos.v23i2.27507 
Nastagio empunha um galho de árvore que encontra no solo e sai em defesa da donzela. Neste momento, o cavaleiro se dirige a Nastagio e explica sua sina - tendo sido perdidamente apaixonado por uma 'cruel' donzela, sem que tivesse seu amor correspondido, o cavaleiro se suicidou e foi, por este pecado, condenado a perseguir sua amada por toda eternidade. Ela, por sua vez, satisfeita com a morte do cavaleiro e sem jamais demonstrar tristeza, ao falecer também foi condenada pela justiça divina a ser eternamente caçada por ele. Após a explicação, os dois fantasmas voltam a encenar o macabro episódio. Os cachorros finalmente alcançam a donzela, que sucumbe às violentas mordidas e cai no chão. 0 cavaleiro então se aproxima e, com sua espada, corta as costas da donzela e retira de seu corpo seu coração 'de pedra', que é jogado aos cães junto com as vísceras do corpo mutilado. Após alguns instantes, a donzela ressuscita e a caçada recomeça. Ainda incapaz de esquecer o objeto de sua paixão, Nastagio então elabora um plano sórdido. Incube seus amigos de convidar a donzela por quem se apaixonou e sua família para um banquete no bosque na semana seguinte. Na ocasião, representada no terceiro quadro da série de Botticelli, após o último prato ser servido, novamente surgem os fantasmas da 'cruel' donzela e do cavaleiro que a persegue. Os presentes reagem imediatamente e logo o cavaleiro desmonta, se aproxima e conta sua história, exatamente como havia feito com Nastagio na semana anterior. No dia seguinte, a donzela pela qual Nastagio havia se apaixonado, aterrorizada com o destino da mulher perseguida no bosque, resolve aceitar seu pedido de casamento. 0 banquete de casamento é representado na quarta e última imagem da série, em que se nota a presença das amigas da donzela à mesa, angustiadas com toda situação. No Decameron, Boccaccio encerra a história relatando que, após o episódio, as mulheres da cidade de Ravena passaram a ser mais condescendentes com os desejos dos homens.

Essa fábula de brutal misoginia, que narra o cruel assassinato de uma mulher cujo único pecado foi não se submeter aos desejos de um homem, assume 
Imagem 3 - Nastagio degli Onesti, primo episodio.

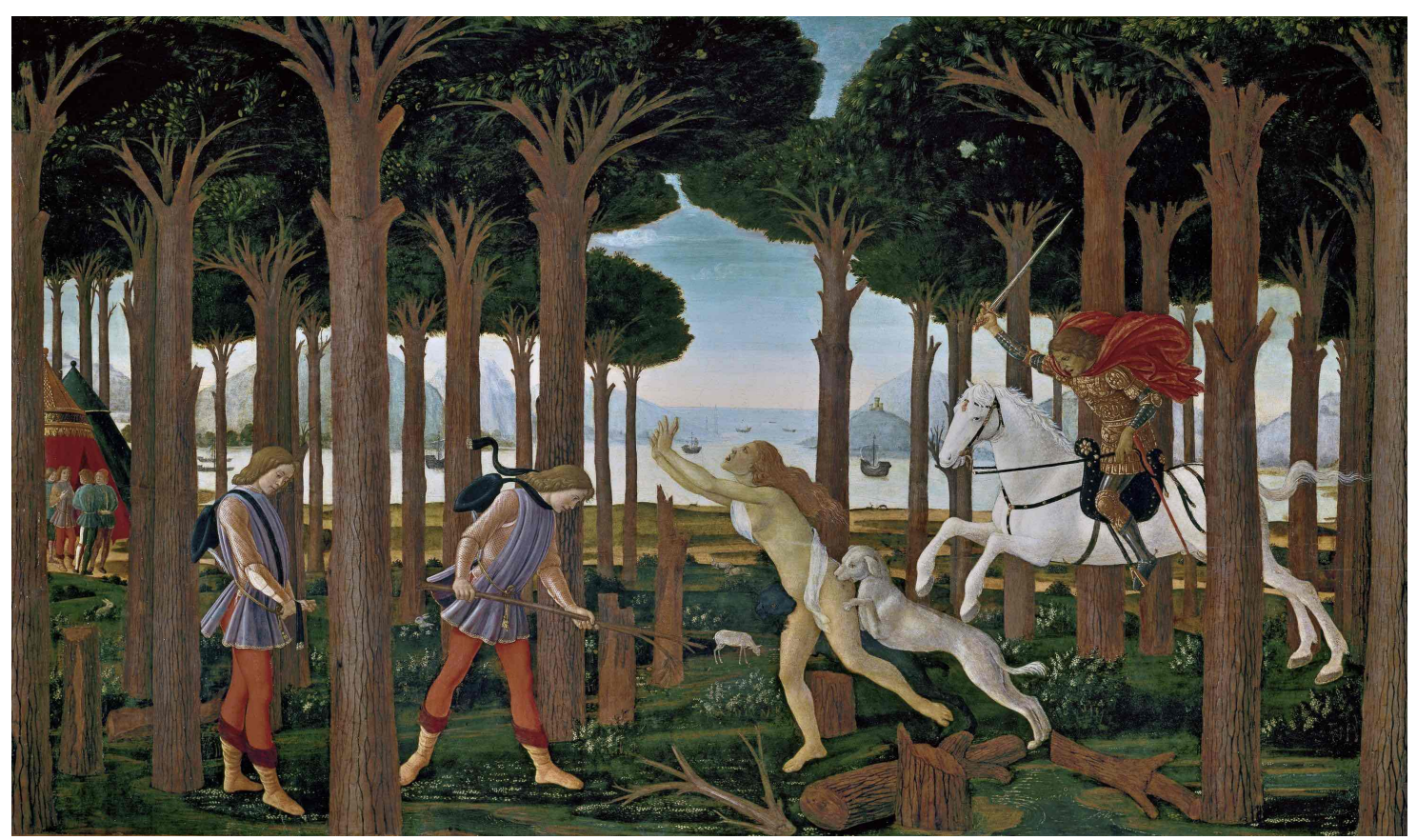

Fonte: Wikipedia

Imagem 4 - Nastagio degli Onesti, secondo episodio.

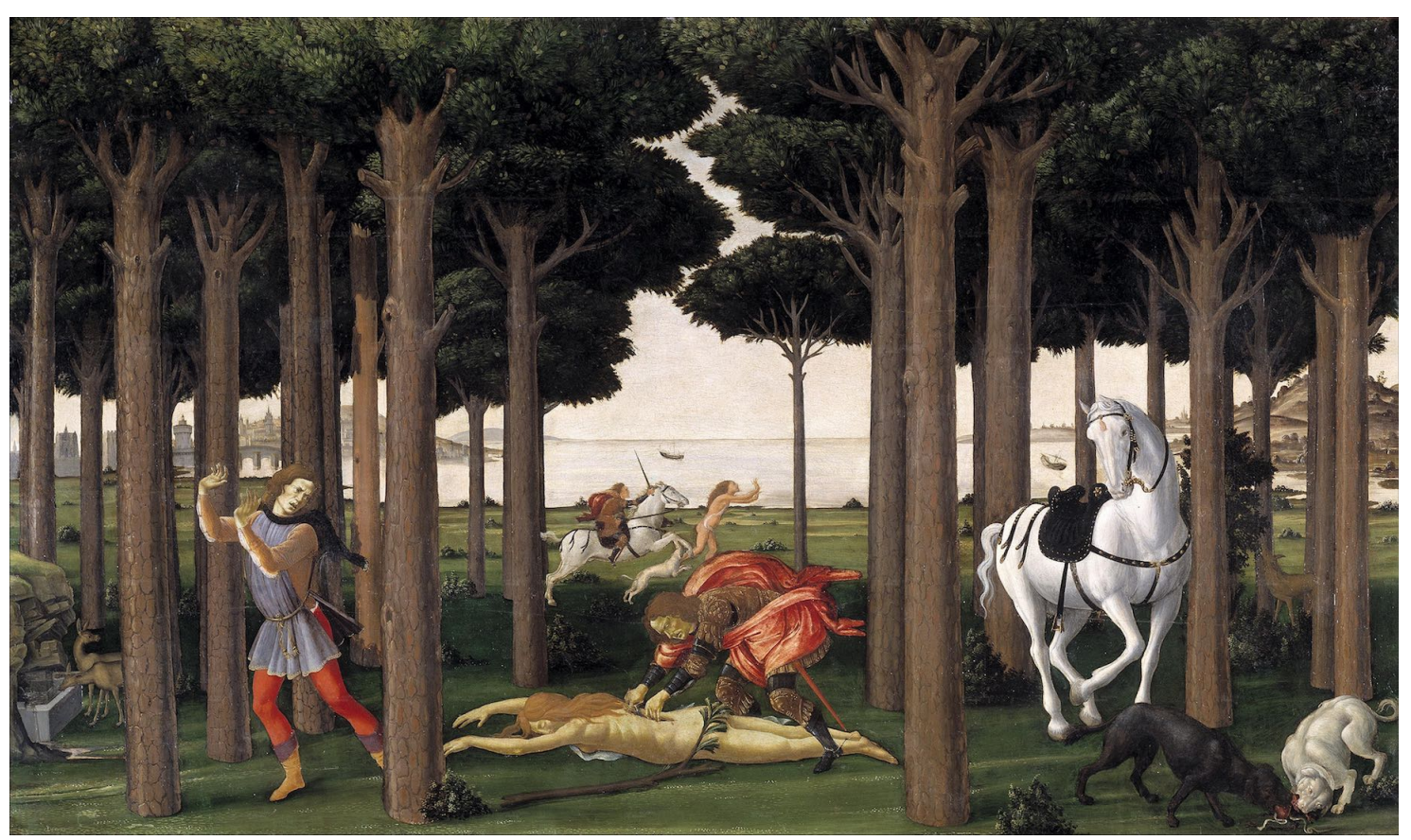

Fonte: Wikipedia

Dossiê 0 Pensamento Ecológico - https://revistaecopos.eco.ufrj.br/

ISSN $2175-8689$ - v. 23, n. 2, 2020

DOI: 10.29146/eco-pos.v23i2.27507 
Imagem 5 - Nastagio degli Onesti, terzo episodio

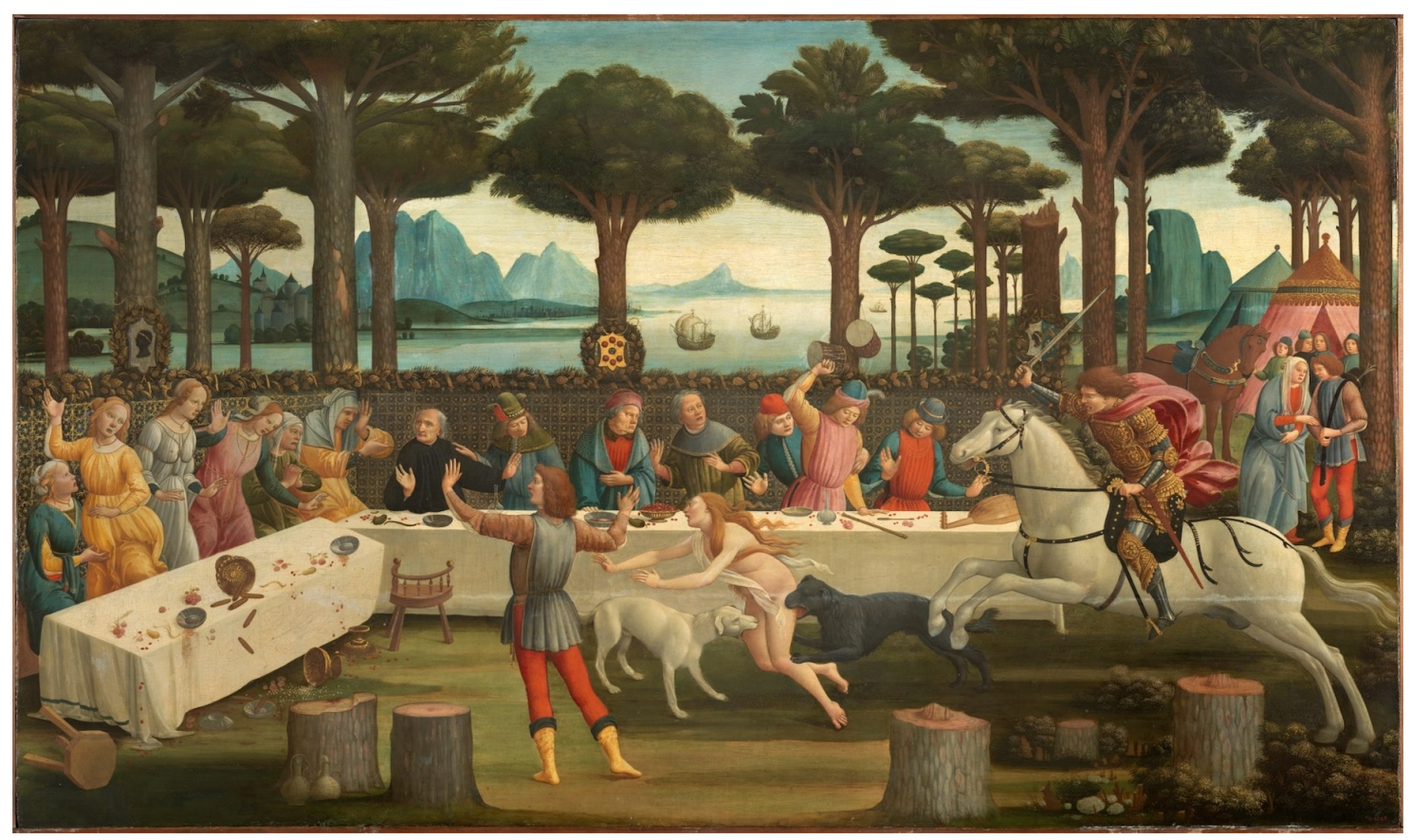

Fonte: Wikipedia

Imagem 6 - Nastagio degli Onesti, quarto episodio

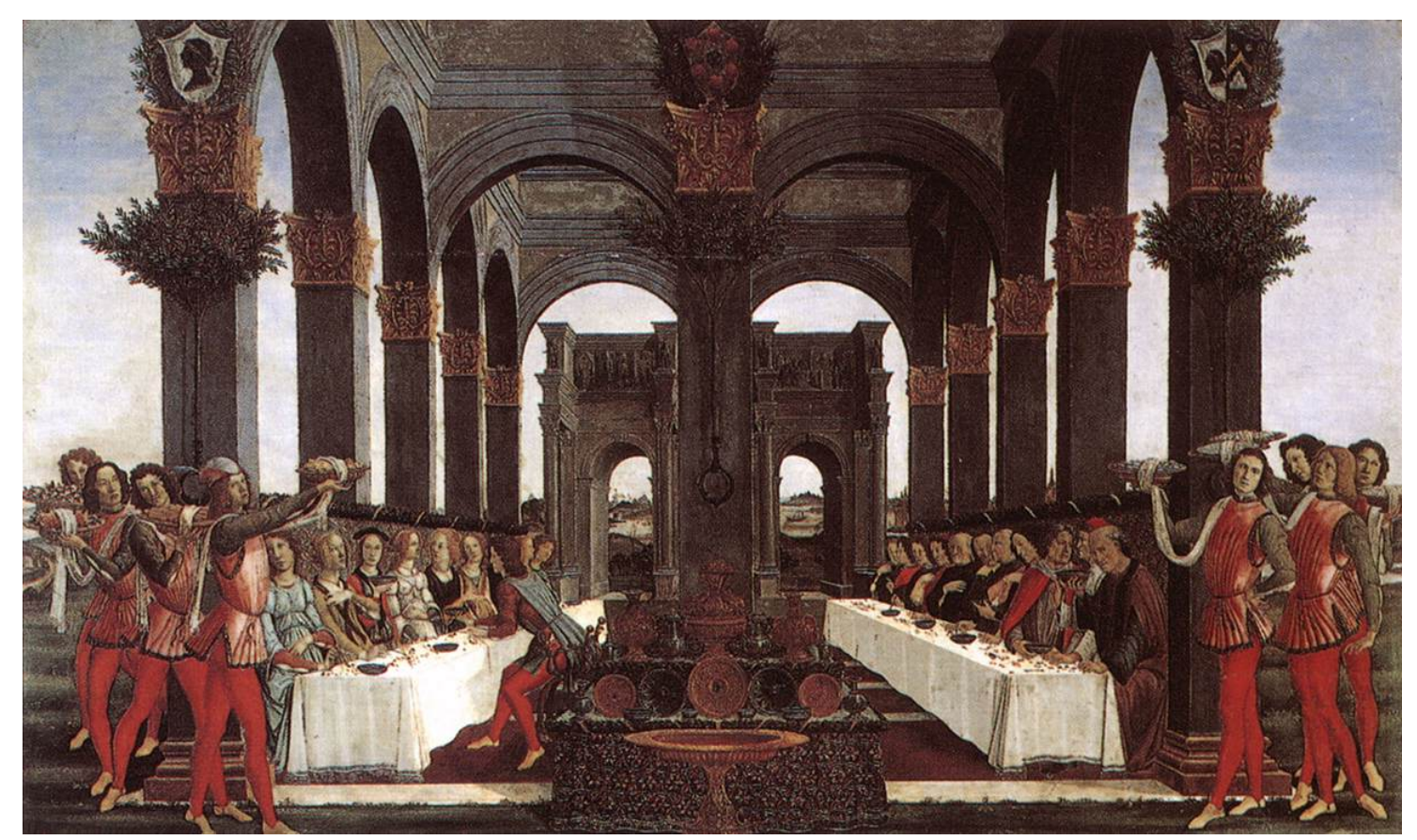

Fonte: Wikipedia

Dossiê 0 Pensamento Ecológico - https://revistaecopos.eco.ufrj.br/

ISSN 2175-8689 - v. 23, n. 2, 2020

DOI: 10.29146/eco-pos.v23i2.27507 
contornos ainda mais macabros quando levamos em conta que a série de Botticelli foi comissionada por Lorenzo de' Medici como um presente de casamento para Giovanni Pucci e sua esposa, Lucrezia Bini. O despudorado terrorismo misógino de Nastagio fez escola na Itália do quattrocento.

A série de quatro pinturas de Botticelli não flagra, no entanto, apenas a violência contra a mulher, mas o continuado processo de destruição da floresta de Chiassi. No primeiro quadro da série, observamos troncos cortados desordenadamente espalhados pelo chão. No banquete no bosque, todas as árvores em primeiro plano foram cortadas e a floresta ao fundo já está menos densa. E, finalmente, na última pintura da série - o casamento de Nastagio - já não encontramos nenhuma árvore sequer. A floresta foi substituída por um conjunto arquitetônico desenhado em perspectiva, que se ergue em meio a um vasto descampado. As árvores deram lugar a imponentes colunas. Nesta célebre série de pinturas de Botticelli, o desmatamento é articulado com a perspectiva unifocal e um enredo profundamente patriarcal, falocêntrico e misógino ${ }^{16}$.

\section{Paisagem e imaginário do desmatamento brasileiro}

A invenção da paisagem também é contemporânea da expansão colonial europeia. Mitchell (2002, p. 5-34) acusa sua relação com o imperialismo. 0 dispositivo da paisagem deu suporte simbólico à transformação da relação com o ambiente, objetificado como recurso a ser explorado e como capital imobiliário. 0 contraste entre as vastas extensões de terra e a reduzida presença de populações nativas nas representações pictóricas das regiões coloniais alimentou a fantasia de

\footnotetext{
${ }^{16} \mathrm{~A}$ relação entre exploração da mulher e exploração de recursos ecossistêmicos, que já se insinua em Veblen, foi trabalhada por autoras identificadas com o ecofeminismo, como María Mies e Vandana Shiva. Ver Ecofeminism (Mies, Shiva, 1993) e outras publicações das autoras, como os clássicos Patriarchy and accumulation on a world scale (Mies, 1986) e Staying Alive: women, ecology and development (Shiva, 1988).
} 
horizonte a ser ocupado - e território a ser conquistado - sustentada pela força centrípeta das linhas de fuga da perspectiva unifocal. As representações de paisagens coloniais produzidas por viajantes europeus acompanharam as reconfigurações dos territórios conquistados em zonas de extração mineral e agropecuária, um processo que muitas vezes se iniciava com a destruição total da paisagem nativa. A cultura predatória (Veblen, 2009, [1899], p.10) que esteve na origem das sociedades feudais se mundializava em busca de novas áreas florestadas.

De fato, ao longo do quattrocento, quando portugueses e espanhóis aportaram nas ilhas da costa atlântica africana, teve início um processo de conquista permeado por encontros e trocas que, em sua violenta assimetria, resultou trágico para a maior parte das populações nativas de humanos, animais e vegetais contactadas pelos viajantes europeus ${ }^{17}$. Na Ilha da Madeira, por exemplo, as densas florestas descritas por contemporâneos da invasão portuguesa ${ }^{18}$ foram paulatinamente dando lugar a encostas nuas, que, ao longo do processo de colonização, foram ocupadas com monoculturas em regime de plantation, como a cana de açúcar. Os imensos troncos extraídos dali alimentaram o fogo dos engenhos e também permitiram que a engenharia naval portuguesa construísse embarcações ainda maiores, pela primeira vez projetadas para a travessia oceânica. E, assim, próximo ao fim do século XV, Colombo aportou na ilha de Hispaniola, no Caribe. Na década seguinte, portugueses liderados por Pedro

\footnotetext{
${ }^{17}$ Sobre encontros coloniais e suas formas de estudo ver Hulme, 1992.

${ }^{18}$ Segundo Thomas Pownall, oficial britânico nas colônias americanas, o globo terrestre "em seu estado nativo, (era) totalmente coberto por florestas", uma imagem que destoava da Europa desmatada do século XVIII. Sobre a Ilha da Madeira, afirmou que ali começava "um novo mundo" (Pownall, 1949 apud Perlin, 1992, p. 263). 0 traficante de escravos veneziano Alvise Cadamosto, descreveu da seguinte maneira a Ilha: "não há um pé (medida imperial) do solo que não esteja coberto por imensas árvores" (Crone, 1937 apud Perlin, 1992, p. 264). Diego Gomes, explorador português, reclamou que "não é possível enxergar o que há no solo, pois há demasiado cedros e outras árvores" (Perlin, 1992, p. 264). Camões, por sua vez, se refere, n'Os Lusíadas, a "grande Ilha da Madeira, / Que do muito arvoredo assim se chama" (Camões, 2000, 5.5, p. 214). Atualmente, da enorme quantidade de madeira que um dia povoou a ilha, restou o nome.
}

\section{Dossiê 0 Pensamento Ecológico - https://revistaecopos.eco.ufrj.br/}

ISSN 2175-8689 - v. 23, n. 2, 2020

DOI: 10.29146/eco-pos.v23i2.27507 
Álvares Cabral alcançaram a costa brasileira. 0 modo europeu de ver e agir sobre o ambiente logo alcançaria as Américas. Em breve, imagens de um 'novo' mundo seriam veiculadas nas iluminuras que preenchiam os muitos espaços ainda 'vazios' nos mapas do continente recém descoberto. O mapa 'Terra Brasilis' (1519), por exemplo, parte do atlas elaborado pelo cartógrafo português Lopo Homem ${ }^{19}$, revela um claro contraste entre o litoral explorado e nomeado com topônimos europeus e o interior desconhecido, preenchido pela fauna, flora, e pela população nativa, curiosamente ocupada no corte de árvores de cerne avermelhado (imagem 7). Contrastando com o imaginário ameríndio em terra firme, o mar aparece repleto de caravelas, brasões e bandeiras, um espaço claramente dominado e riscado pela geometria das linhas de orientação das cartas portulanas.

No topo do mapa há uma legenda em latim, característica da cartografia portuguesa do século XVI, que diz:

Esta carta é da região do grande Brasil e do lado ocidental alcança as Antilhas do Rei de Castela. Quanto à sua gente, é de cor um tanto escuro. Selvagem e crudelíssima, alimenta-se de carne humana. Este mesmo povo emprega, de modo notável, o arco e as setas. Aqui [há] papagaios multicores e outras inúmeras aves e feras monstruosas. E encontram-se muitos gêneros de macacos e nasce em grande quantidade a árvore que, chamada brasil, é considerada conveniente para tingir o vestuário com a cor púrpura. (Guerreiro, 1999. p. 120)

A vegetação nativa está presente em todo o território, mas apenas uma única espécie arbórea é representada - o pau-brasil. 0 olhar especista dos exploradores portugueses enxerga a natureza como recurso a ser explorado, e assim, na síntese cartográfica de Lopo Homem, o pau-brasil - principal recurso natural explorado então - figura praticamente sozinho nas florestas atlânticas

19 O mapa Terra Brasilis é parte do conjunto conhecido como Atlas Miller, elaborado pelo cartógrafo da corte Lopo Homem, e contou com a colaboração dos também cartógrafos Pedro e Jorge Reinel, e ilustrado pelo artista Antonio de Holanda, que, presume-se pelo sobrenome, seria originário dos Países Baixos.

Dossiê O Pensamento Ecológico - https://revistaecopos.eco.ufrj.br/

ISSN $2175-8689$ - v. 23, n. 2, 2020

DOI: 10.29146/eco-pos.v23i2.27507 
Imagem 7 - Mapa Terra Brasilis

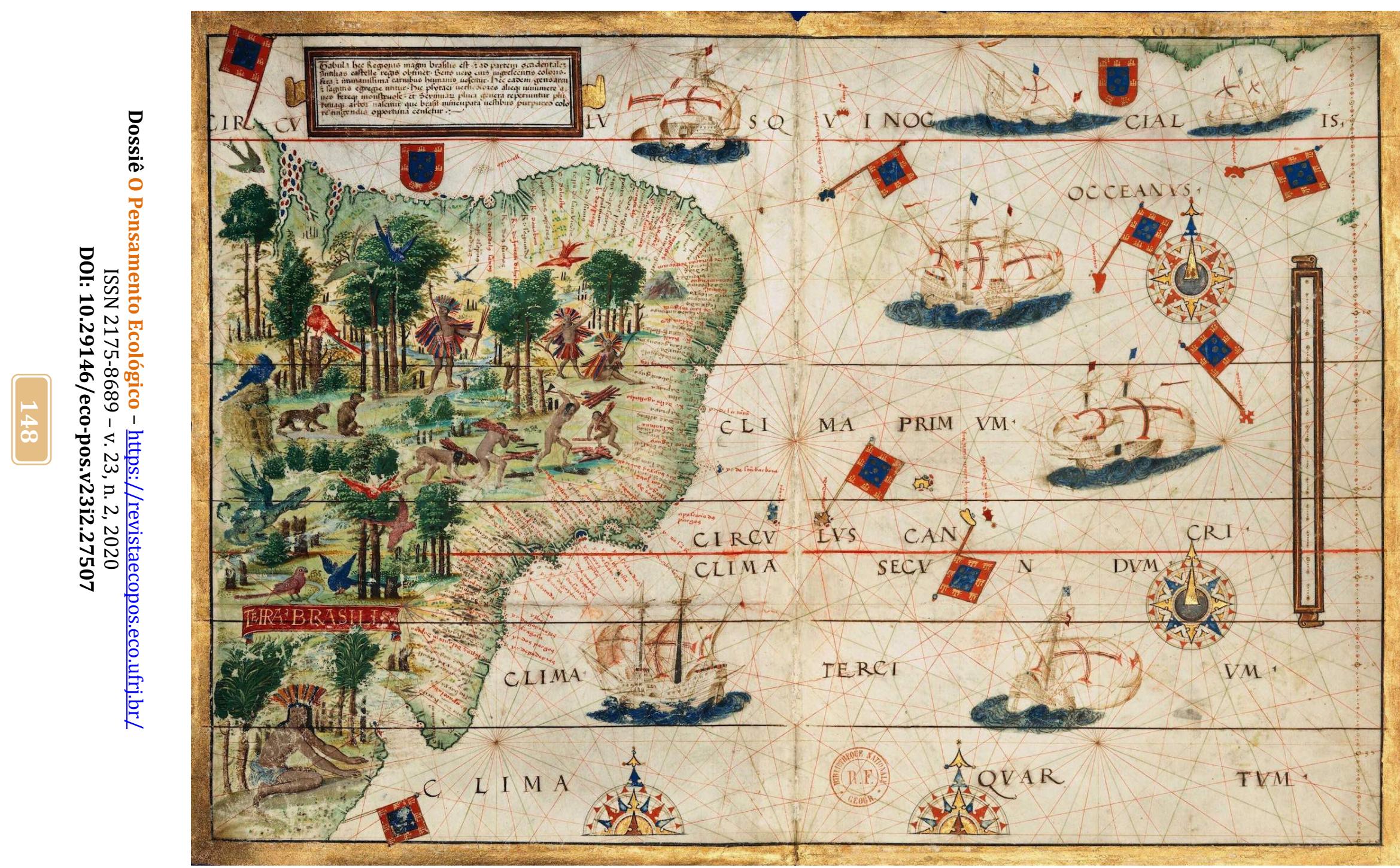

Fonte: BN Digital, Biblioteca Virtual de Cartografia Histórica

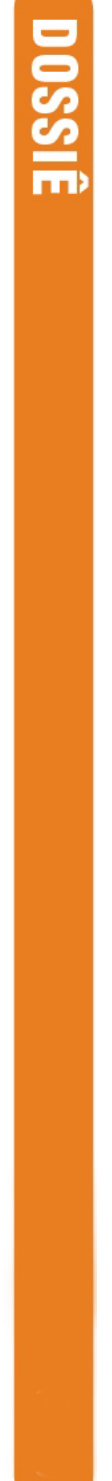


sulamericanas $^{20}$. A presença da espécie passou a identificar a região, e se no planisfério de Cantino ela nomeava o rio próximo a Porto Seguro onde a expedição de Gonçalo Coelho encontrou grande quantidade de pau-brasil, na carta de Lopo Homem a árvore já nomeava toda a parte ocidental do continente, sob domínio português - Terra brasilis ${ }^{21}$. Publicada menos de duas décadas após a expedição de Pedro Álvares Cabral, a iluminura no mapa de Lopo Homem é considerada a primeira imagem de desmatamento no Brasil (Mapa, 1993).

A representação de índios derrubando árvores e transportando toras de madeira avermelhadas se tornaria um elemento constante nos mapas da região, mas é na carta de Jean Rotz, publicada em seu Boke of Idrography (c. 1535-1542 [1942]), que encontramos a mais detalhada representação da extração do pau-brasil nas Américas (imagem 8). Rotz, cartógrafo e navegador francês do porto normando de Dieppe, esteve no Brasil em 1539 e testemunhou em pessoa a interação entre europeus e brasileiros que produziu o lucrativo comércio de madeira tintorial. Não obstante o monopólio decretado pela coroa portuguesa, Dickason (1984, p. 129-146) identificou, apenas na Normandia, 226 licenças de comércio de pau-brasil já nas primeiras décadas do século XVI, período no qual Rouen, a principal cidade da região, figurava como um dos mais importantes centros têxteis e tintureiros da Europa. 0 cerne do pau-brasil era utilizado em uma ampla gama de tinturas que produziam matizes que iam do encarnado ao púrpura. Sua versatilidade o tornava uma matéria-prima valiosa, e a tora extraída da árvore se transformou em preciosa commodity 22 . Como o monarca francês não reconhecia

\footnotetext{
200 mapa Terra Brasilis também representa arbustos e ao menos uma espécie de palmeira no território sulamericano.

210 mapa de Lopo Homem e Reinés é considerado o primeiro a indicar a unidade territorial da futura colônia portuguesa.

22 Depois de retiradas casca e alburno dos troncos, preservando apenas o cerne avermelhado, e cortadas em seções uniformes que pesavam entre 20 e 30 kilos (para facilitar o transporte), defendemos que as toras de pau-brasil se tornavam uma commodity: passavam a apresentar
}

\section{Dossiê 0 Pensamento Ecológico - https://revistaecopos.eco.ufrj.br/}

ISSN 2175-8689 - v. 23, n. 2, 2020

DOI: 10.29146/eco-pos.v23i2.27507 
Imagem 8 - Carta da costa ocidental da América do Sul e parte da Terra do Fogo
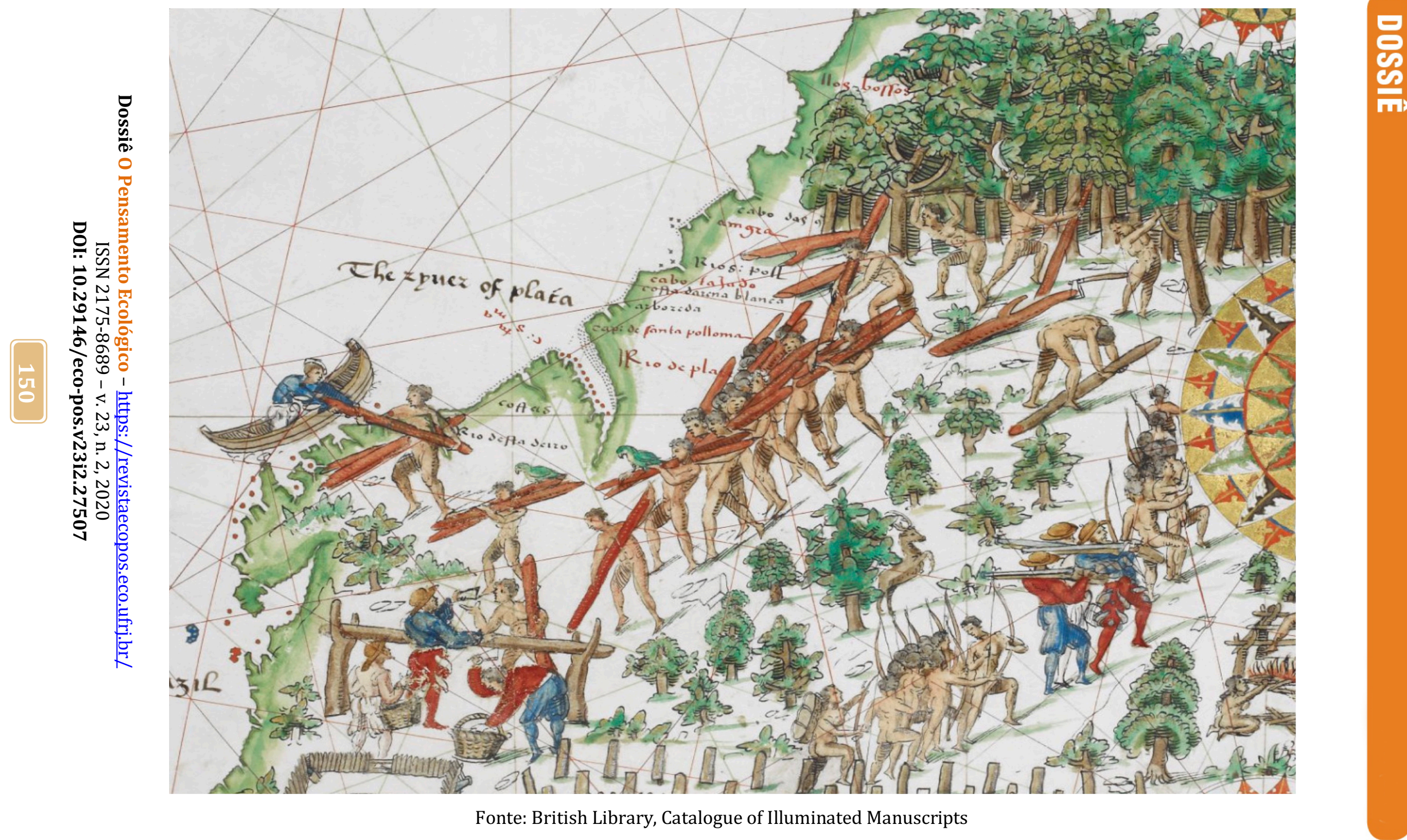

Fonte: British Library, Catalogue of Illuminated Manuscripts 
o Tratado de Tordesilhas, que dividiu o mundo entre as potências ibéricas, armadores normandos se lançaram ao comércio direto com comunidades tupinambás da Terra brasilis e, já em 1504, negociavam pau-brasil, penas de aves, peles de animais, papagaios e escravos com os indígenas ${ }^{23}$.

Diferentemente dos portugueses, que instalaram feitorias ao longo da costa, os franceses da Normandia optaram por não erigir edificações em terra, preferindo abandonar tripulantes nas aldeias indígenas para que aprendessem a língua dos nativos de modo a, em expedição subsequente, servirem como intérpretes, intermediando a extração e o tráfico de madeira. Indivíduos tupinambás também embarcaram nas caravelas e seguiram para a Europa com os entrelopos normandos ${ }^{24}$.

A indústria tintureira, que transformou a paisagem costeira sulamericana e as sociedades tupinambás, também determinou mudanças na paisagem e

\begin{abstract}
qualidades e características uniformes, podiam ser estocadas por determinado período sem perda significativa de qualidade, já não eram diferenciadas de acordo com sua origem, tinham seu preço uniformemente determinado pela oferta e procura internacional. Para seu completo enquadramento como commodity, só lhes faltavam a cotação e negociabilidade global através de bolsas de valores, ainda incipientes no século XVI. No entanto, por constituírem elemento emblemático da emergência do sistema-mundo capitalista-colonialista, especialmente a partir da perspectiva brasileira, defendemos que essa última exigência deva ser modulada. 0 tráfico transatlântico de pau-brasil antecipou o mercado global de commodities. A rigor, poderíamos nos referir ao pau-brasil como uma proto-commodity.
\end{abstract}

${ }^{23}$ Wintroub (2006, p. 21-22) especula que navegadores normandos já negociavam ao longo da costa sul-americana desde antes da descoberta oficial pelos portugueses em 1500.

${ }^{24}$ A esse respeito, é emblemática a história de Içá-mirim (Formiga Pequena, em tupi; chamado Essomeriq pelos franceses), filho de Arosca, líder dos Carijós na atual Ilha de São Francisco do Sul (Santa Catarina), que foi enviado à França a bordo do navio normando L'Espoir para aprender a arte da artilharia. A 150 kilômetros do porto de Honfleur, no entanto, o navio foi atacado por piratas e naufragou. A tragédia impediu o capitão Binot Paulmier de Gonneville de cumprir a promessa de devolver o jovem ao pai. O capitão Gonneville, que havia batizado Essomeriq com o próprio nome durante a viagem, decidiu então casá-lo com sua filha, tornando-o herdeiro de todas suas propriedades. Içá-mirim viveu em Honfleur como um cidadão conhecido e respeitado até falecer em 1583, aos 94 anos. A maior parte dos ameríndios trazidos a Europa, no entanto, não tiveram a mesma sorte de Içá-mirim. Sobre a história de Içá-Mirim/Essomeriq, ver Perrone-Moisés, Leyla. 'Vinte Luas - Viagem de Paulmier de Gonneville ao Brasil (1503-1505)'. São Paulo: Companhia das Letras, 1996.

Dossiê O Pensamento Ecológico - https://revistaecopos.eco.ufrj.br/

ISSN $2175-8689$ - v. 23, n. 2, 2020

DOI: 10.29146/eco-pos.v23i2.27507 
sociedade normanda. 0 imaginário brasileiro ${ }^{25}$ passou a fazer parte da cultura urbana de Rouen, e motivos ameríndios adornavam edificações da cidade. 0 frontispício de madeira que encimava a fachada do Hôtel l'Isle-du-Brésil é um exemplo da presença do imaginário ameríndio no espaço público de Rouen. Um baixo-relevo entalhado em duas longas tábuas de carvalho, medindo aproximadamente meio metro de altura por dois metros de comprimento cada, dispostas lado a lado, o conjunto instalado no número 17 da Rue Malpalu, narra uma cena que se desenrola da direita para a esquerda (imagem 10). Um grupo de indígenas derrubam árvores de pau-brasil na floresta e transportam a madeira até a costa. Os homens usam machados de ferro e as mulheres trabalham as toras, retirando com uma machadinha a casca e o alburno dos troncos, preservando apenas o cerne utilizado no tingimento. 0 procedimento se fazia necessário para reduzir o tamanho e o peso das peças de madeira, facilitando o transporte (Dean, 1995, 45).

Os ameríndios são representados em dramático contrapposto ${ }^{26}$ (imagem 9), com corpos torneados típicos da antiguidade clássica e volumosas barbas. Com feições europeias, apenas a nudez os distingue da tripulação normanda. A atmosfera heroica sublinha o esforço brutal exigido pela extração do pau-brasil. No

\footnotetext{
${ }^{25}$ Franceses e portugueses se referiam aos ameríndios que colaboravam na extração de pau-brasil por 'brasileiros'. De fato, o sufixo '-eiro', pouco utilizado na formação de gentílicos, é comumente utilizado para indicar agência ou profissão. Faroleiro é aquele que trabalha no farol; garimpeiro, quem garimpa metais e pedras preciosas; jornaleiro, quem vende jornal, e assim por diante. Os gentílicos que utilizam este sufixo mantém, em geral, o duplo significado, como no caso de 'mineiro' - tanto quem nasce no estado de Minas Gerais quanto aquele que trabalha na mineração - ou 'brasileiro', o nativo do Brasil ou aquele que trabalha na extração do pau-brasil. Segundo o filólogo Silveira Bueno "No tempo colonial, 'brasileiro' era adjetivo que indicava profissão: tirador de paubrasil." (Rodrigues, 2013)

26 "O contrapposto clássico é um termo utilizado em escultura para assinalar uma forma de representação humana que busca a naturalidade, em contraposição às representações rígidas e artificiais presentes na escultura até então. Essa característica, inovação grega, é constituída pela distribuição harmônica e natural do peso da figura representada em pé, com uma perna flexionada e a outra sendo a principal sustentação desse peso. Assim, a figura adquire um caráter de movimento natural tanto de frente quanto de lado." Contrapposto. In Wikipédia: a enciclopédia livre. Disponível em: https://pt.wikipedia.org/wiki/Contrapposto. Acesso em: 8 mai 2020.
}

Dossiê 0 Pensamento Ecológico - https://revistaecopos.eco.ufrj.br/

ISSN $2175-8689$ - v. 23, n. 2, 2020

DOI: 10.29146/eco-pos.v23i2.27507 
canto esquerdo, um jovem sentado como no famoso bronze helênico Lo spinario é outra referência clássica. Junto a ele, dois homens e uma mulher que dá a mão a uma criança evocam um núcleo familiar. Muitos papagaios ${ }^{27}$ testemunham a cena, cujo desenvolvimento culmina com a entrega da madeira para uma tripulação normanda fundeada próxima a praia. A paisagem acompanha o desenrolar da narrativa: a densa floresta à direita progressivamente dá lugar a um grupo de rochas e pequenos arbustos. Os animais já não se abrigam nas árvores encontramo-los no solo, sobre as toras de madeira carregada pelos indígenas, ou nos inúmeros tocos que se acumulam na floresta devastada. A copa das árvores é gradualmente substituída por pequenas nuvens no céu. Testemunhamos o desmatamento da mata atlântica sulamericana.

Algo, no entanto, distingue o baixo-relevo de Rouen das demais obras reunidas nesse ensaio: agora o desmatamento acontece no primeiro plano, deixou de figurar como um detalhe da paisagem e se tornou fundamental ao tema central da imagem, o tráfico de madeira ${ }^{28}$. A cena entalhada nos painéis de carvalho se distingue do imaginário edênico que caracteriza os primeiros relatos dos 'descobrimentos' quinhentistas. Ela flagra um exemplo emblemático da salvage accumulation mencionada por Anna Tsing29: a apropriação capitalista de valores

\footnotetext{
${ }^{27}$ Alguns mapas do início do século XVI, como o Globo de Johannes Schöner (1520), se referem ao atual território brasileiro pelo termo em latim 'papagalli terra' (em português, terra dos papagaios). O papagaio assumiu então função metonímica, a simbolizar o 'novo' mundo ao sul, além de figurar como produto subsidiário na exploração europeia do continente recém 'descoberto'. (Souza, 2001, p. 67).

${ }^{28} \mathrm{O}$ desmatamento só se tornaria tema central em imagens do século XIX, fruto de um ambiente cultural marcado pela emergência do ideário iluminista e por doutrinas econômicas como a fisiocracia. Durante o período, no Brasil, a incipiente crítica ambiental articulada por intelectuais como José Bonifácio de Andrada e Silva também se expressou visualmente em obras de, entre outros, Rugendas, Taunay e Weingärtner. Ainda investigo a relação entre crítica ambiental e produção pictórica brasileira no século XIX, o que deve em breve resultar em novo artigo sobre o tema.

29 "Where do capitalist resources come from? Capitalists are unable to make most of their resources. Consider oil and coal, those formerly living products whose formation has required so much more time than capitalists can imagine. Capitalists use them, but they cannot manufacture them. This is not just true for ancient things. Capitalism makes use of animal digestion and plant
}

Dossiê 0 Pensamento Ecológico - https://revistaecopos.eco.ufrj.br/

ISSN 2175-8689 - v. 23, n. 2, 2020

DOI: 10.29146/eco-pos.v23i2.27507 
produzidos em sua periferia e além, através de complexos assemblages $^{30}$ socioambientais de seres humanos e não-humanos. Ao talhar casca e alburno dos troncos tomados à floresta, a mulher tupinambá representada no baixo-relevo inadvertidamente produzia a commodity que iria ser convertida em lucro de armadores normandos do outro lado do Atlântico. O trabalho em família e comunitário, que reunia diferentes gerações, é outro índice do contexto nãocapitalista em que se dava a apropriação das riquezas que iriam impulsionar o desenvolvimento europeu.

O painel da esquerda traz em seu centro o ápice dramático da narrativa: o contato da tripulação europeia com os ameríndios. Olhos nos olhos, o marujo normando encara o tupinambá enquanto ele lhe entrega uma pesada tora de paubrasil. Representados com a boca entreaberta, os dois parecem conversar. Como assinala Buono (2016, p.25), as duas figuras são praticamente idênticas simetricamente posicionados, igualmente curvados, as mãos em correspondência.

photosynthesis without having any clue how to shape these processes, despite the sophisticated engineering of plants and animals. In agribusiness, milk and grain created in these non-capitalist processes are translated into capitalist value. These are the processes I call "salvage accumulation." Accumulation is the amassment of wealth under capitalism; salvage here refers to the conversion of stuff with other histories of social relations (human and not human) into capitalist wealth." (Tsing, 2015b).

30 "The concept of assemblage is helpful. Ecologists turned to assemblages to get around the sometimes fixed and bounded connotations of ecological "community." The question of how the varied species in a species assemblage influence each other-if at all-is never settled: some thwart (or eat) each other; others work together to make life possible; still others just happen to find themselves in the same place. Assemblages are open-ended gatherings. They allow us to ask about communal effects without assuming them. They show us potential histories in the making. For my purposes, however, I need something other than organisms as the elements that gather. I need to see lifeways - and non-living ways of being as well -coming together. Nonhuman ways of being, like human ones, shift historically. For living things, species identities are a place to begin, but they are not enough: ways of being are emergent effects of encounters. Thinking about humans makes this clear. Foraging for mushrooms is a way of life-but not a common characteristic of all humans. The issue is the same for other species. Pines find mushrooms to help them use humanmade open spaces. Assemblages don't just gather lifeways; they make them. (...) Patterns of unintentional coordination develop in assemblages. To notice such patterns means watching the interplay of temporal rhythms and scales in the divergent lifeways that gather. Surprisingly, this turns out to be a method that might revitalize political economy as well as environmental studies." (Tsing, 2015, p. 22-23)

Dossiê 0 Pensamento Ecológico - https://revistaecopos.eco.ufrj.br/

ISSN 2175-8689 - v. 23, n. 2, 2020

DOI: 10.29146/eco-pos.v23i2.27507 


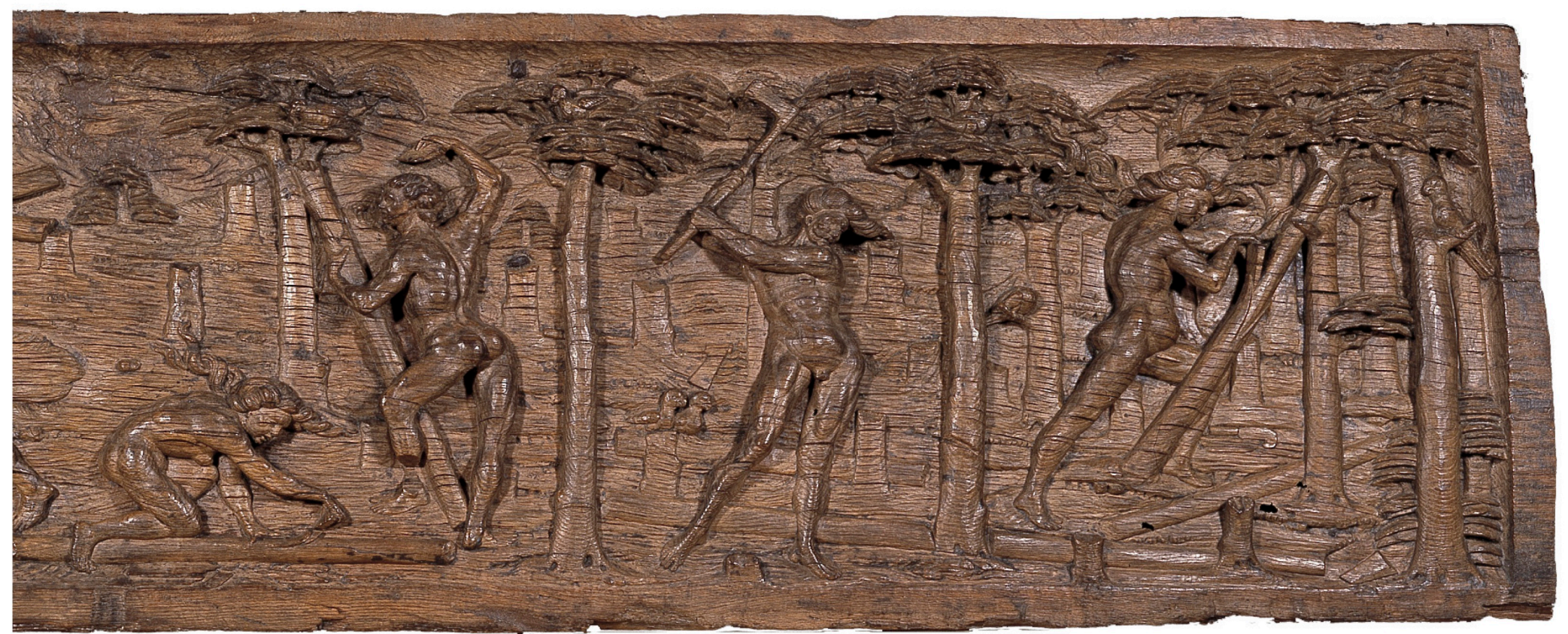

Fonte: @ Musée-Métropole-Rouen-Normandie - Cliché Yohann Deslandes, François Dugué 
Novamente, apenas a nudez do indígena distingue-o do francês. Esses detalhes ajudam a construir a fantasia de uma troca socioeconômica harmônica e equilibrada que sabemos distante da realidade profundamente assimétrica da relação entre amerabas e europeus.

Conhecidos na França medieval como enseignes, painéis na fachada que identificavam social, religiosa ou profissionalmente seus moradores ainda eram comuns na Europa dos primeiros anos do Renascimento. E, diante do mistério acerca da identidade do proprietário do Hotel l'Isle-du-Brésil à época, pesquisadores especulam se tratar de um rico comerciante ligado ao tráfico de pau-brasil ou defendem que o lugar abrigava indígenas brasileiros de passagem pela cidade (Hamy, Delsalle, p. 372; Dickason, p. 135 apud Buono, 2016). Tanto num caso como no outro, não se tratava de alguém interessado em comissionar uma peça de arte que explicitasse a violência imbricada no comércio de madeira tintorial.

As imagens do mapa de Jean Rotz revelam com maior nitidez a provável natureza da relação entre ameríndios e franceses: a troca de bens materiais. A longa fila de indígenas que deixam a floresta carregando toras de pau-brasil termina num balcão improvisado com troncos de madeira, onde um homem europeu oferece um objeto que se assemelha a um machado em troca da tora de madeira avermelhada entregue pelo indígena. A ferramenta é a mesma observada no corte das árvores na parte superior da imagem. Uma relação de escambo, portanto, não de trabalho (Buono, 2016, p. 28). As iluminuras dos mapas de Lopo Homem e Rotz e os painéis do Hotel l'Isle-du-Brésil revelam a intervenção na paisagem socioambiental produzida pela presença europeia na América do Sul quinhentista. Ao mesmo tempo, instauram um imaginário europeu sobre o 'novo' mundo, repleto de persistentes estereótipos sobre a população autóctone e a floresta.

Dossiê 0 Pensamento Ecológico - https://revistaecopos.eco.ufrj.br/

ISSN 2175-8689 - v. 23, n. 2, 2020

DOI: 10.29146/eco-pos.v23i2.27507 
Imagem 10 - Painel da fachada do Hôtel l' Isle-du-Brésil (painéis esquerdo e direito)
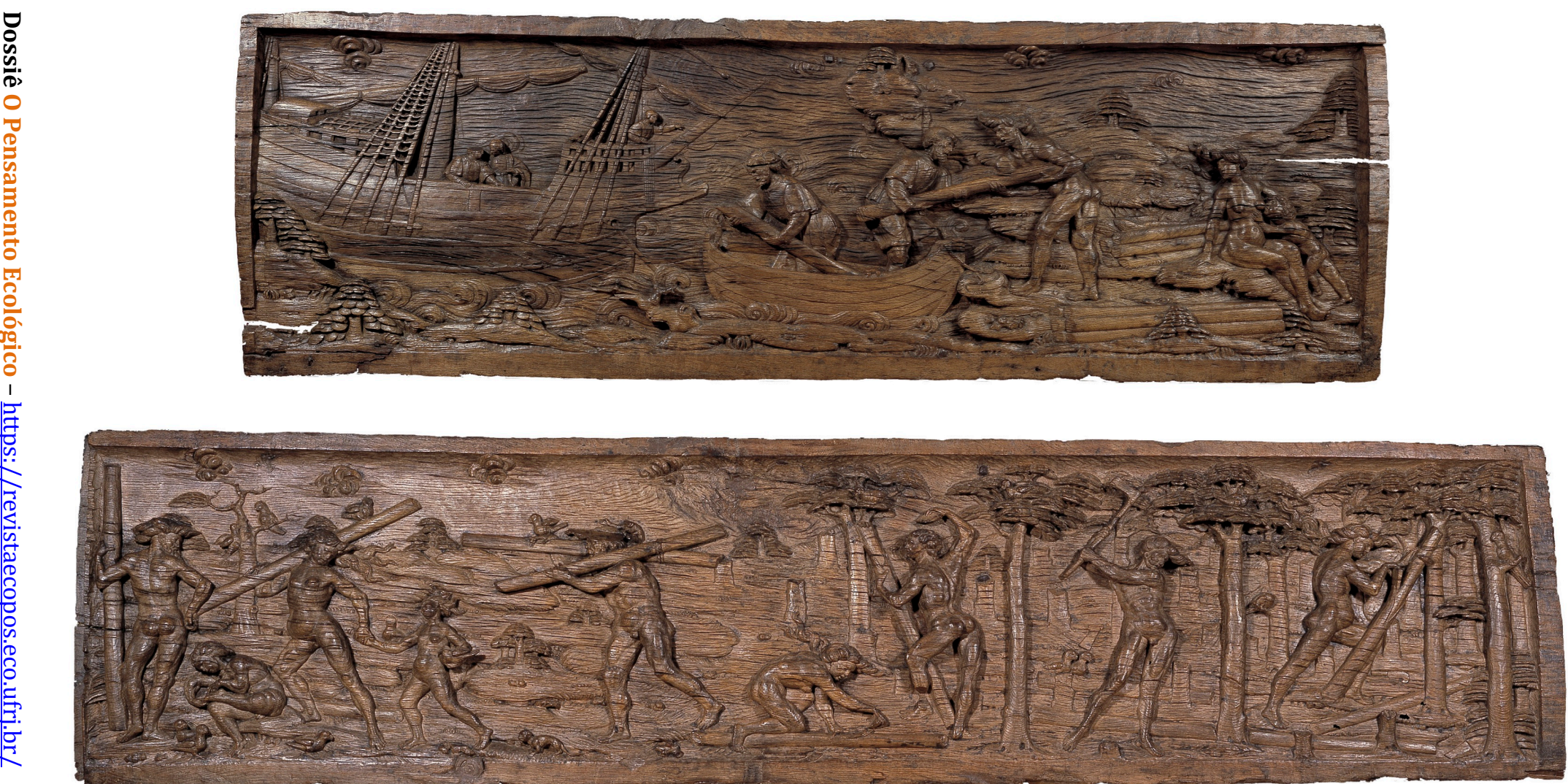

Fonte: @ Musée-Métropole-Rouen-Normandie - Cliché Yohann Deslandes, François Dugué 
O homem que desmata (jamais uma mulher) e seus rastros são os sintomas que mobilizaram a reunião do grupo heterogêneo de imagens trabalhadas neste ensaio. Dispersas em diferentes suportes, técnicas, períodos e estilos, estas imagens, quando reunidas, propõem uma visada incômoda, que acusa o caráter de nossa relação com o ambiente. Com sorte, podem ser capazes de instaurar uma inflexão da ideia de progresso que norteia o desenvolvimento de nossas sociedades contemporâneas. Até quando devemos aceitar desempenhar o papel de agentes de nosso próprio colapso, como os ameríndios representados no baixo-relevo em madeira de Rouen, ou nos mapas de Rotz e Lopo Homem? Aqueles homens e mulheres e crianças de pele avermelhada como o tronco de madeira que carregavam nos braços, a atender a demanda do capitalista europeu - então chamados por 'brasileiros'.

\section{Memória e desmatamento}

Ao flagrar o desmatamento em ação em obras tão distintas quanto o livro de horas do Duque de Berry, a Caçada na floresta de Paolo Uccello, o mapa 'Terra Brasilis' de Lopo Homem, ou o frontispício do Hôtel l'Isle-du-Brésil, nosso objetivo neste texto não foi traçar nenhum tipo de evolução linear ou coerência morfológica na representação desse motivo. 0 desmatamento aparece de diferentes formas e expressa relações diversas. Por vezes, as arvores caídas são apenas um detalhe, um signo discreto que ressignifica um enredo mais amplo. Por outras, a retirada das árvores está no foco da representação, constituindo o motivo principal das imagens. Sendo assim, paisagem e perspectiva aparecem aqui como 'formas simbólicas' (Panofsky, 1997), expressão e agente dos processos de desmatamento e colonização.

A coleção de imagens reunida por esse texto, agrupada através de um motivo comum, tem inspiração direta nos trabalhos de Aby Warburg. Opondo-se à

\section{Dossiê O Pensamento Ecológico - https://revistaecopos.eco.ufrj.br/}

ISSN $2175-8689$ - v. 23, n. 2, 2020

DOI: 10.29146/eco-pos.v23i2.27507 
história da arte enquanto evolução das técnicas de representação ou identificação de períodos estanques, o pesquisador alemão propôs uma metodologia com quadros combinatórios, séries de séries a criar conjuntos de imagens que se relacionam entre si por meio de formas e motivos. Em seu último trabalho, o Atlas Mnemosyne, Aby Warburg articulou esculturas, pinturas, desenhos e recortes de jornal que foram combinados e recombinados de maneira anacrônica, respeitando critérios definidos pelo historiador. Com este atlas, Warburg inaugurou uma nova forma de ver a arte - um pensamento por imagens - que influenciou muitos trabalhos posteriores (Didi-Huberman, 2013).

O sistema conhecido como Iconclass (Lavin, 1993), criado pelo historiador da arte holandês Henri van de Waal, por exemplo, configura uma continuidade dessa maneira tipicamente warbuguiana de abordar a arte por meio de motivos ou assuntos. Waal desenvolveu um sistema para classificar os objetos de arte em base temática. Nesse sistema, as obras são primeiramente organizadas em nove temas por exemplo, arte abstrata; religião e magia; natureza; ser humano; entre outros. Cada um desses temas compreende novos desdobramentos, considerando novamente os assuntos tratados. A natureza, por exemplo, se divide em mais nove temas - terra, fenômenos naturais, tempo, corpos celestiais, entre outros. 0 desmatamento, no entanto, não é um motivo destacado nem nos arranjos de Warburg, nem na classificação proposta por Waal.

Ao reunir as imagens trabalhadas, buscamos ir além da mera ilustração de um argumento, na direção de evidenciar como um grupo de imagens pode ser conectado a partir de um texto. E o texto (ou argumento) central é claro: as imagens do desmatamento nos acompanham e nos assombram, evidenciando a naturalização de uma relação de força e apropriação do ambiente associada ao desenvolvimento das cidades e à expansão do colonialismo. Inalterado o caráter violento de nossa relação com a paisagem, que, embora nos constitua, é concebida 
como aquilo que nos rodeia, a sobrevivência desse motivo em esculturas, mapas e pinturas seguirá acompanhando nossas histórias.

\section{Referências bibliográficas}

ALIGHIERI, Dante. A Divina Comédia. São Paulo: Atena Editora, 2003.

ALLOA, Emmanuel. Entre a transparência e a opacidade - o que a imagem dá a pensar. In: ALLOA, Emmanuel (org.). Pensar a Imagem. Belo Horizonte: Autêntica Editora, 2015, p. 7-19.

ANÔNIMO. A Epopeia de Gilgamesh. São Paulo: Martins Fontes, 2011.

BERQUE, Augustin. Thinking through landscape. Nova York: Routledge, 2013.

BUONO, Amy. Representing the Tupinambá and the Brazilwood Trade in SixteenthCentury Rouen. In: FÉLIX, Regina R.; JUALL, Scott D. (org.). Cultural Exchanges between Brazil and France. West Lafayette: Purdue University Press, 2016, p. 19-34.

BURKE, Peter. Testemunha ocular: história e imagem. Bauru, SP: EDUSC, 2004.

CAMÕES, Luís de. Os Lusíadas. Lisboa: Instituto Camões, 2000.

COSGROVE, Denis E. Social Formation and Symbolic Landscape. Madison: University of Wisconsin Press, 1998 [1984].

CRONE, Gerald R. (org). The Voyages of Cadamosto and Other Documents on Western Africa in the Second Half of the Fifteenth Century. Londres: Hakluyt Society, 1937.

DEAN, Warren. With Broadax and Firebrand: The Destruction of the Brazilian Atlantic Forest. Berkeley: University of California, 1995.

DIDI-HUBERMAN, Georges. The Surviving Image: Aby Warburg and Tylorian Anthropology. In: Oxford Art Journal, Volume 25, Issue 1, p. 59-69. Oxford: Oxford University Press, 2002. Disponível em https://academic.oup.com/oaj/articleabstract/25/1/59/1449629. Acesso em 13 mar 2020.

DIDI-HUBERMAN, Georges. A imagem sobrevivente: história da arte e tempo dos fantasmas segundo Aby Warburg. Rio de Janeiro: Contraponto, 2013.

HULME, Peter. Colonial Encounters: Europe and the Native Caribbean, 1492-1797. London: Routledge, 1992.

KOPENAWA, Davi. Urihi A. In: ALBERT, Bruce; MILLIKEN, William (org.). Urihi a: a terrafloresta yanomami. São Paulo: Instituto Socioambiental, 2009.

Dossiê 0 Pensamento Ecológico - https://revistaecopos.eco.ufrj.br/

ISSN $2175-8689$ - v. 23, n. 2, 2020

DOI: 10.29146/eco-pos.v23i2.27507 
KWIATKOWSKA, Teresa. The sadness of the wood is bright: deforestation and conservation in the middle ages. In: Medievalia n. 39. Mexico, DF: Universidade Autónoma de México, 2007.

LAVIN, Irving. Iconography as a Humanistic Discipline ("Iconography at the Crossroads"). In: CASSIDY, B. Iconography at the Crossroads. Papers from the Colloquium sponsored by the Index of Christian art Princeton University. Princeton University Press, 1993.

GINZBURG, C. Morfologia e História. São Paulo. Companhia das Letras, 1989.

GOMBRICH, E. H. Aims and Limits of Iconology. In: The Essential Gombrich. Londres: Phaidon, 1996.

MENESES, Ulpiano T. Bezerra de. A paisagem como fato cultural. In: YÁGIZI, Eduardo (org.). Turismo e Paisagem. São Paulo: Contexto, 2002.

MITCHELL, W. J. T. Imperial Landscape. In: MITCHELL, W. J. T. (org.) Landscape and Power. Chicago: University of Chicago Press, 2002.

MONDZAIN, Marie-José. A imagem entre proveniência e destinação. In: ALLOA, Emmanuel (org.). Pensar a Imagem. Belo Horizonte: Autêntica Editora, 2015, p. 39-54.

NOVAES, A. R. Geografia e História da Arte: Apontamentos para uma crítica a Iconologia. Espaço e Cultura, n.33, p. 43-64. 2013.

OPPENHEIM, A. Babylonian and Assyrian Historical Texts. In: PRITCHARD, J. (org) Ancient Near Eastern Texts Relating to the Old Testament. New Jersey: Princeton University Press, 1969.

PANOFSKY, Erwin. Significado nas Artes Visuais. São Paulo: Ed. Perspectiva, 1978 [1955].

PANOFSKY, Erwin. Perspective as Symbolic Form. New York: Zone Books, 1997 [1925].

PERLIN, John. História das Florestas. Rio de Janeiro: Imago Editora, 1992.

POWNALL, Thomas. A topographical description of the dominions of the United States of America. Pittsburgh: University of Pittsburgh Press, 1949.

RODRIGUES, Sérgio. 'Brasileiro', a palavra, já nasceu pegando no pesado. Blog 'Sobre palavras' (Revista Veja). São Paulo, 30 abr. 2013. Disponível em:

https://veja.abril.com.br/blog/sobre-palavras/brasileiro-a-palavra-ja-nasceu-pegandono-pesado/ Acesso em 7 set 2019.

SOUZA, Laura de Mello e. 0 nome do Brasil. In: Revista de História, n. 145, 2001, p. 61-86.

TSING, Anna Lowenhaupt. The mushroom at the end of the world: on the possibility of life in capitalist ruins. New Jersey, Princeton University Press, 2015.

Dossiê 0 Pensamento Ecológico - https://revistaecopos.eco.ufrj.br/

ISSN $2175-8689$ - v. 23, n. 2, 2020

DOI: 10.29146/eco-pos.v23i2.27507 
TSING, Anna Lowenhaupt. Salvage Accumulation, or the Structural Effects of Capitalist Generativity. In Theorizing the Contemporary, Fieldsights, March 30, 2015b. Disponível em: https://culanth.org/fieldsights/salvage-accumulation-or-the-structural-e ects-ofcapitalist- generativity. Acesso em: 7 mai 2020.

VEBLEN, Thorstein. A theory of the leisure class. Nova York: Oxford University Press, 2009 [1899].

VIDAL, Laurent. La présence française dans le Brésil colonial au XVIe siècle. In: Cahiers des Amériques latines, n.34, p.17-38. Paris: Institut des hautes études de l'Amérique latine, 2000. Disponível em http://journals.openedition.org/cal/6486. Acesso em 2 mai 2020.

WHISTLER, Catherine. Paolo Uccello's The Hunt in the Forest. Oxford: Ashmolean Museum, 2001.

\section{Referências visuais}

ANÔNIMO. Painel da fachada do Hôtel l'Isle-du-Brésil (direito). c. 1530-1550 Baixo-relevo em madeira, 52 x $221 \mathrm{~cm}$. /Imagem 9 e 10

ANÔNIMO. Painel da fachada do Hôtel l'Isle-du-Brésil (esquerdo). c. 1530-1550 Baixorelevo em madeira, 53 x $170 \mathrm{~cm}$. /Imagem 10

BOTTICELLI, Sandro. Nastagio degli Onesti, primo episodio. 1483. Pintura, têmpera sobre madeira, 83 x $138 \mathrm{~cm}$. /Imagem 3

BOTTICELLI, Sandro. Nastagio degli Onesti, secondo episodio. 1483. Pintura, têmpera sobre madeira, $82 \times 138 \mathrm{~cm}$. / Imagem 4

BOTTICELLI, Sandro. Nastagio degli Onesti, terzo episodio. 1483. Pintura, têmpera sobre madeira, 83 x $142 \mathrm{~cm}$. / Imagem 5

BOTTICELLI, Sandro. Nastagio degli Onesti, quarto episodio. 1483. Pintura, têmpera sobre madeira, 83 x $142 \mathrm{~cm}$. / Imagem 6

HOMEM, Lopo; REINEL; Pedro; REINEL, Jorge; HOLANDA, Antonio de. Mapa Terra Brasilis. 1519. Mapa iluminado. / Imagem 7

LIMBOURG, Paul de. Février, folio 2. In: Les Très Riches Heures du duc de Berry. FRÈRES DE LIMBOURG; VAN EYCK, Barthelémy (?); COLOMBE, Jean. 1411-1416, 1440, 1485-1486. Livro de iluminuras medieval, 29 x $21 \mathrm{~cm}$. / Imagem 1

ROTZ, Jean. Carta da costa ocidental da América do Sul e parte da Terra do Fogo. In: Boke of Idrography. c. 1535-1542. Mapa iluminado, 52 x $30 \mathrm{~cm}$. / Imagem 8

UCCELLO, Paolo. Caccia notturna. 1470. Pintura, têmpera sobre madeira, 65 x $165 \mathrm{~cm}$. / Imagem 2

Dossiê 0 Pensamento Ecológico - https://revistaecopos.eco.ufrj.br/

ISSN $2175-8689$ - v. 23, n. 2, 2020

DOI: 10.29146/eco-pos.v23i2.27507 